\title{
Circumpolar patterns in Antarctic krill larval recruitment: an environmentally driven model
}

\author{
Sally E. Thorpe*, Geraint A. Tarling, Eugene J. Murphy \\ British Antarctic Survey, Natural Environment Research Council, Cambridge CB3 0ET, UK
}

\begin{abstract}
Larval recruitment in Antarctic krill is known to be episodic and regional. We consider the importance of a range of recruitment factors using an environmentally driven model of larval development from spawning to post-larvae. Our model examines the timing of spawning, interaction with bathymetry, susceptibility to cold temperatures, temperature-driven development and the seasonal cycle of sea ice to identify those factors with the greatest impact. The model predicts that the seasonal location of sea ice is the main limiting factor for successful larval recruitment. Spawning in January leads to the greatest area of viable larval recruitment habitat. Dense sea ice cover, which we assume that adult krill do not spawn under, prevents spawning in large areas early in the breeding season (December). Nevertheless, later spawning in February, when sea ice is at a minimum, means there is often insufficient time for the larvae to reach a viable developmental stage before the sea ice advances. Meanwhile, although spawning is possible in more northerly areas throughout the breeding season, these are generally remote from winter sea ice, which is assumed to be necessary for larvae to overwinter. Interaction with bathymetry before hatching further limits suitable habitat. Over a $12 \mathrm{yr}$ period, the model predicted larval recruitment from January spawning in all years in the Cooperation, Ross and Weddell Seas, with episodic larval recruitment in the Bransfield Strait in 9 of the 12 years. Additional understanding of the overwintering requirements of larvae, together with regional studies at higher spatial resolution, particularly in shelf regions, will better constrain the uncertainties in the model.
\end{abstract}

KEY WORDS: Antarctic krill · Euphausia superba - Southern Ocean · Sea ice - Larval ecology Larval mortality $\cdot$ Recruitment $\cdot$ Individual-based model

\section{INTRODUCTION}

The life cycle of a species is a major determinant of its response to environmental variability and change and is key to defining its overall distributional range. In oceanic environments, early developmental stages are often considered to be the most vulnerable to environmental factors (Byrne 2011), and their ability to develop and grow while withstanding the often variable nature of their environment is the principal driver of successful recruitment. In polar environments, extreme seasonality is a major limitation on recruitment, since it constrains the period of spawning, development and growth to short windows of time (Clarke 1988, Conover \& Huntley 1991, Smeta-

\footnotetext{
${ }^{*}$ Corresponding author: seth@bas.ac.uk
}

cek \& Nicol 2005). Furthermore, distributional range is often restricted by the development and decay of seasonal sea ice, because although it can be a haven to some species or specific life-cycle stages, it can be a barrier to others (Thomas \& Dieckmann 2002).

Antarctic krill Euphausia superba is a key species in the Southern Ocean. The main prey of a number of marine predators, it is also the target of a commercial fishery and contributes to biogeochemical cycles (Croxall et al. 1999, Murphy et al. 2007, Ratnarajah \& Bowie 2016, Schmidt et al. 2016, Tarling \& Thorpe 2017). In an effort to understand the drivers of its distribution, model studies of Antarctic krill are increasingly concentrating on the circumpolar scale and are considering critical periods of the krill life

() The authors 2019. Open Access under Creative Commons by Attribution Licence. Use, distribution and reproduction are unrestricted. Authors and original publication must be credited. 
cycle (Thorpe et al. 2007, Melbourne-Thomas et al. 2016, Piñones \& Fedorov 2016, Murphy et al. 2017, Mori et al. 2019). Spatial heterogeneity in the ability of krill to survive their first winter is considered one of the major restrictions on successful recruitment to the adult population (Loeb et al. 1997, Atkinson et al. 2004) and is therefore key to determining subsequent population distribution.

The early life cycle of Antarctic krill comprises 5 embryonic development stages and 12 larval stages. Peak spawning occurs in austral summer (DecemberFebruary; Quetin et al. 1994). Although gravid females have been observed at depth (Clarke \& Tyler 2008), the prevailing theory is that eggs are spawned at the ocean surface and then sink during embryonic development to depths of several hundred metres, taking around 5-8 d to hatch (Marr 1962, Marschall 1983, Quetin \& Ross 1984, Ross et al. 1988, Jia et al. 2014). On hatching, the larvae swim to the surface using their internal carbon reserves through 2 naupliar and a metanaupliar stage until reaching the first calyptopis stage and developing the capability to feed. The later larval stages comprise 3 calyptope and 6 furcilia stages and are generally found in the upper $250 \mathrm{~m}$ of the water column (Fraser 1936). Rates of development are principally temperature dependent, and the transition from eggs to post-larvae can take around 4 mo (Ikeda 1984). Several studies have observed late-stage furcilia as the most common larval stages in early winter (Fraser 1936, Daly 1990, 2004, Frazer et al. 2002), suggesting that younger stages are not as viable at this time of the year.

Successful recruitment of larval krill can be limited by several factors. Ovarian maturation to the point of spawning requires good feeding conditions, bringing into question the viability of the under-sea ice habitat as a successful spawning ground (Cuzin-Roudy \& Labat 1992, Melnikov \& Spiridonov 1996). Recent observations of spent female krill in the Lazarev Sea in areas of dense sea ice concentration suggest that krill can spawn in the marginal ice zone, likely fuelled by increased productivity associated with polynyas (Kawaguchi et al. 2010, Siegel 2012). Once spawned, it is assumed that embryo development must be completed before contact with the sea floor to avoid predation and damage to the embryo (Hofmann \& Hüsrevoğlu 2003, Piñones \& Fedorov 2016). The depletion of carbon reserves during the ascent of the non-feeding stages of larvae is inversely proportional to in situ temperature. However, even in temperatures of $-1{ }^{\circ} \mathrm{C}$, the depletion of initial carbon reserves is well within the starvation threshold for krill larvae and is therefore not considered to limit successful development (Ross \& Quetin 1989, Hofmann et al. 1992). Temperature can have a direct impact on the survival of larval krill, with evidence that exposure to very cold temperatures $\left(-1^{\circ} \mathrm{C}\right)$ during the early life stages can prevent development beyond the calyptopis 1 stage (Ross et al. 1988).

Successful larval recruitment is further limited by food availability for larval krill. The lipid reserves of larval krill are insufficient to sustain the larvae for long periods of starvation. The first feeding stages have a starvation threshold (point of no return) of 10-14 d (Ross \& Quetin 1989), with tolerance to starvation increasing with larval stage (Daly 2004). At high latitudes in winter, when light levels are low, sea ice-associated biota are believed to be vital for larvae (Daly 1990, Meyer et al. 2002, 2017, Meyer 2012, Kohlbach et al. 2017). Older larval stages are able to scrape sea ice algae from the underside of sea ice (Frazer et al. 1997), but the earlier calyptope stages lack feeding appendages to do this and so must rely on food in the water column, either in the open ocean or released from sea ice, which may therefore determine successful larval recruitment.

Studies of habitat suitability for early larval stages of krill have considered the development trajectory from spawning of eggs to re-emergence in surface waters of early-stage larvae south of $60^{\circ} \mathrm{S}$ (Hofmann et al. 1992, Hofmann \& Hüsrevoğlu 2003). In these studies, successful completion of the developmental descent-ascent cycle occurred in all waters deeper than $1000 \mathrm{~m}$, and in restricted regions of the continental shelf where warmer waters are present at depth. Elsewhere on the shelf, the eggs reached the seafloor before they hatched, deeming these regions unsuccessful. Piñones \& Fedorov (2016) extended this work to consider the survival of the larvae through to the first winter, introducing starvationbased mortality during 3 periods of the early life cycle: after surfacing as calyptope stages, during the summer and autumn and during winter. This restricted the regions of successful development to areas in the Weddell Sea, East Antarctica, the Ross and Bellingshausen Seas and parts of the western Antarctic Peninsula (WAP).

The present study advances these earlier studies and uses an individual-based development model for the early life stages of Antarctic krill from spawning to the first winter. The model builds on the developmental descent-ascent model of Hofmann et al. (1992) to include temperature-driven development for the later larval stages and key mortality events. Furthermore, we consider the factors that may result in successful overwintering, i.e. where larvae reach a 


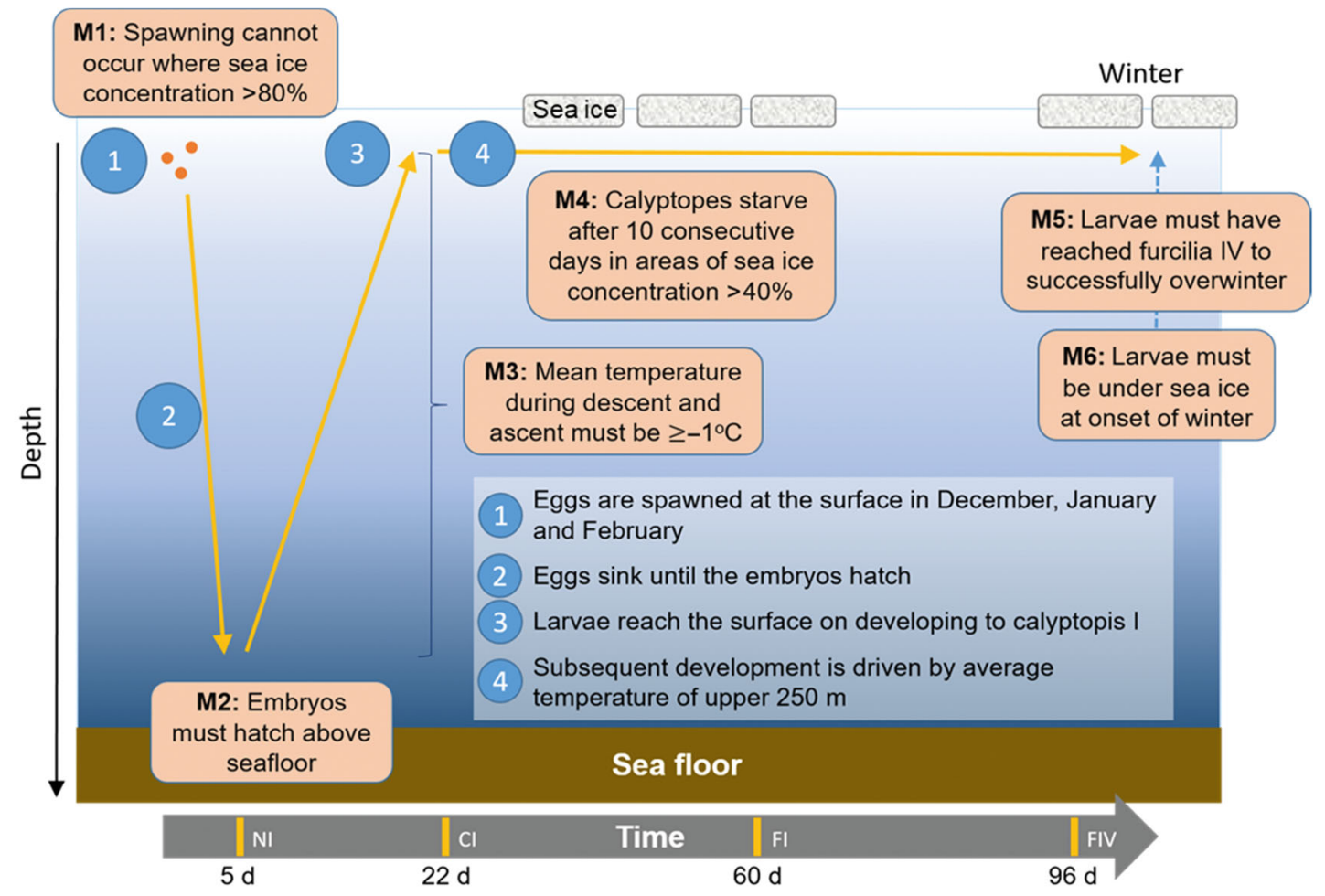

Fig. 1. Overview of the Antarctic krill larval recruitment model and its mortality assumptions. Circles 1 to 4 outline the model steps, and boxes M1 to M6 indicate the requirements (mortality rules) for successful larval recruitment (see Table 2 for further details). Values on the time axis indicate the number of days from spawning to reach key developmental stages at a constant temperature of $0^{\circ} \mathrm{C}$. NI: nauplius I, i.e. hatching; CI: calyptopis I; FI: furcilia I; FIV: furcilia IV (Ikeda 1984, Hofmann et al. 1992)

sufficiently advanced developmental stage and are under sea ice by early winter (Fig. 1). Our specific objectives were to: (1) determine whether implementing current mortality assumptions reproduces areas of known larval krill recruitment in the circumpolar Southern Ocean; (2) assess whether there is intra-seasonal variability in the modelled regions of larval recruitment; (3) investigate the drivers of regional larval recruitment failure in the model $;$ and (4) examine interannual variability in the seasonal sea ice cycle on the patterns of larval recruitment. The model is targeted on large-scale patterns of habitat suitability. Larvae will travel through these habitats on advective trajectories (e.g. Mori et al. 2019), and this aspect was not included in the present study. However, within a large oceanic context, our aim was to identify those areas on which trajectory-based analyses should be focussed.

\section{METHODS}

To simulate larval recruitment of Antarctic krill, we used a model that determines the development of krill larvae from spawning to the following onset of winter. Mortality rules were incorporated into the model to assess the relative impact of potential sources of mortality. The model was run for 3 spawning events in the peak spawning season (December, January and February) to investigate the sensitivity to timing of spawning.

\subsection{Development of krill embryos and larvae}

\subsubsection{Developmental descent-ascent of embryos and larvae}

The early part of the krill life cycle was modelled in 2 parts, the descent of the embryo following spawning at the ocean surface until hatching, and the ascent of the larva as it returns to the surface. The depth and timing of hatching were modelled following Hofmann et al. (1992). The rate of sinking of the embryo depends on the diameter of the embryo, its density relative to the surrounding water and the development stage of the embryo, which is a function of temperature (described in Section 2.1.2). Earlier models of larval ascent that used a temperaturedependent rate of ascent and assumed that the larvae spend a fixed proportion of time swimming (Hofmann et al. 1992, Hofmann \& Hüsrevoğlu 2003, 
Piñones \& Fedorov 2016) can result in earlier larval stages reaching the ocean surface than are observed, particularly in warmer waters. Here we assumed that the larva reaches the surface on metamorphosis to the first feeding stage, calyptopis 1 (CI), consistent with observations that naupliar stages are generally found at depth (Hempel 1985, Hempel \& Hempel 1986). The overall result of applying our new method is that the ascent rate is less sensitive to variation in temperature with ascent rates of $3.5 \times 10^{-4}$ to $4.0 \times$ $10^{-4} \mathrm{~m} \mathrm{~s}^{-1}$ for a temperature range of -1 to $+3^{\circ} \mathrm{C}$. These rates compare with values of $3.3 \times 10^{-4}$ to $6.7 \times$ $10^{-4} \mathrm{~m} \mathrm{~s}^{-1}$ using the function of Hofmann et al. (1992) assuming that the larvae spend $20 \%$ of the time swimming. The largest difference between the 2 methods occurs at the warmest temperatures. Once hatched, larval development is also a function of temperature (also described in Section 2.1.2), and the mean temperature of the water column from hatching depth to the surface is used to calculate the duration of the non-feeding stages of the larva, specifically the naupliar and metanaupliar stages. This then determines the timing of the larva's ascent.

\subsubsection{Stage-specific development functions}

Our development model uses stage-specific temperature-dependent development functions for the 5 embryo stages and 12 larval stages of krill development. Embryo development was modelled following Hofmann et al. (1992) determining the respective durations of the stages single cell to early gastrula, early gastrula to gastrula, gastrula to early limb bud, early limb bud to late limb bud, and late limb bud to hatching of naupliar I. Stage-specific temperaturedependent development durations were calculated for the 12 larval stages (NI, NII, metanauplius [MN], CI-CIII, furcilia FI-FVI) based on the premise of equiproportional development in Antarctic krill (Ross et al. 1988), i.e. that relative durations of developmental stages remain the same, independent of temperature. Ross et al. (1988) also considered the effect of temperature on the duration of single stages, developing both an exponential and Bělehrádek model (Bělehrádek 1957) to predict stage duration as a function of temperature. We used their exponential model for the time taken for an embryo to hatch to determine the influence of temperature on developmental times, noting that their other functions were broadly similar. This exponential model was extrapolated to cover the temperature range -1 to $+4^{\circ} \mathrm{C}$. The duration of each larval stage from NI to FVI at $0^{\circ} \mathrm{C}$ was extracted from Ikeda (1984). Stage-specific duration times at other temperatures were derived in $1{ }^{\circ} \mathrm{C}$ increments as follows:

$$
d_{s, t}=\frac{d_{e, 0^{\circ} \mathrm{C}}}{d_{e, t}} \times d_{s, 0^{\circ} \mathrm{C}}
$$

where $d$ is development time (days), $s$ is larval developmental stage (NI to FVI), $t$ is temperature $\left({ }^{\circ} \mathrm{C}\right)$, and $e$ is the embryo to hatch stage.

Interpolation between the $1^{\circ} \mathrm{C}$ increments to enable developmental time to be derived at intermediate temperatures was determined by fitting a 3-parameter exponential decay function of the form:

$$
f=y_{0}+a e^{-b t}
$$

where $f$ is the stage-specific development time (days), $t$ is temperature $\left({ }^{\circ} \mathrm{C}\right)$, and $b$ was determined to be 1.0479. The stage-specific values for $y_{0}$ and $a$ are provided in Table 1, together with stage-specific development times for a range of temperatures. The major sensitivity in the development relationship is at extremely low temperatures (Table 1), and the degree of uncertainty in extrapolating the development relationship to $4^{\circ} \mathrm{C}$ as described above is therefore small $( \pm 3 \%$ between assuming no change and extrapolated change between these 2 temperatures over the entire larval development cycle).

\subsection{Mortality assumptions}

Six requirements for successful larval recruitment based on mortality assumptions from the literature were implemented in the larval recruitment model (Table 2, Fig. 1). These 'mortality rules' rely on sea ice distribution and timing of advance, bathymetry and temperature.

\subsection{Model input fields}

The larval recruitment model is forced with monthly mean temperature and density fields from the 20052007 solution of the Southern Ocean State Estimate (SOSE; Mazloff et al. 2010) for the period December 2005 to May 2006. SOSE is an eddy-permitting general circulation model of the Southern Ocean with a horizontal resolution of $1 / 6^{\circ} \times 1 / 6^{\circ}$ and 42 vertical levels of varying thickness ranging from $10 \mathrm{~m}$ at the surface to $142 \mathrm{~m}$ at $1000 \mathrm{~m}$. SOSE is fitted by constrained least squares to in situ and remotely sensed oceanographic data to provide a physically realistic estimate of the ocean state. Although a surface-inten- 
Table 1. Parameters for Eq. (2) (see Section 2.1.2) to derive temperature-dependent larval stage duration of Antarctic krill (days) and estimated larval stage durations relative to temperature. $\mathrm{N}$ : nauplius, $\mathrm{MN}$ : metanauplius, $\mathrm{C}$ : calyptopis, $\mathrm{F}$ : furcilia. Also given are embryo development time (days; Hofmann et al. 1992) and total time to complete the larval phase (days)

\begin{tabular}{|c|c|c|c|c|c|c|c|c|}
\hline \multirow[t]{2}{*}{ Stage } & \multicolumn{2}{|c|}{$\begin{array}{l}\text { Exponential decay } \\
\text { function values }\end{array}$} & \multicolumn{6}{|c|}{-Developmental stage durations (d) - } \\
\hline & $y_{0}$ & a & $-1^{\circ} \mathrm{C}$ & $0^{\circ} \mathrm{C}^{\mathrm{a}}$ & $1^{\circ} \mathrm{C}$ & $2^{\circ} \mathrm{C}$ & $3^{\circ} \mathrm{C}$ & $4^{\circ} \mathrm{C}$ \\
\hline NI & 3.9446 & 1.0560 & 7.0 & 5.0 & 4.3 & 4.1 & 4.0 & 4.0 \\
\hline NII & 5.5225 & 1.4784 & 9.7 & 7.0 & 6.0 & 5.7 & 5.6 & 5.6 \\
\hline $\mathrm{MN}$ & 7.8892 & 2.1120 & 13.9 & 10.0 & 8.6 & 8.2 & 8.0 & 7.9 \\
\hline $\mathrm{CI}$ & 11.0449 & 2.9568 & 19.5 & 14.0 & 12.1 & 11.4 & 11.2 & 11.1 \\
\hline CII & 7.1003 & 1.9008 & 12.5 & 9.0 & 7.8 & 7.3 & 7.2 & 7.1 \\
\hline CIII & 7.8892 & 2.1120 & 13.9 & 10.0 & 8.6 & 8.2 & 8.0 & 7.9 \\
\hline FI & 9.4671 & 2.5344 & 16.7 & 12.0 & 10.4 & 9.8 & 9.6 & 9.5 \\
\hline FII & 8.6871 & 2.3232 & 15.3 & 11.0 & 9.5 & 9.0 & 8.8 & 8.7 \\
\hline FIII & 10.2560 & 2.7456 & 18.1 & 13.0 & 11.2 & 10.6 & 10.4 & 10.3 \\
\hline FIV & 10.2560 & 2.7456 & 18.1 & 13.0 & 11.2 & 10.6 & 10.4 & 10.3 \\
\hline FV & 11.8338 & 3.1680 & 20.9 & 15.0 & 13.0 & 12.2 & 12.0 & 11.9 \\
\hline FVI & 9.4671 & 2.5344 & 16.7 & 12.0 & 10.4 & 9.8 & 9.6 & 9.5 \\
\hline \multicolumn{3}{|c|}{ Embryo developmental time (d) } & 8.4 & 6.1 & 5.2 & 4.8 & 4.6 & 4.6 \\
\hline \multicolumn{3}{|c|}{$\begin{array}{l}\text { Total development time from } \\
\text { spawning to juvenile (d) }\end{array}$} & 191 & 137 & 118 & 116 & 109 & 108 \\
\hline \multicolumn{3}{|c|}{ Values from Ikeda (1984) } & & & & & & \\
\hline
\end{tabular}

sified warm temperature anomaly is present in SOSE in the southern Weddell Sea (Mazloff et al. 2010), the effects of this anomaly over the upper $250 \mathrm{~m}$ in which the modelled larvae spend the majority of their time are small.

To calculate the development and sinking rates of the descending embryo, the descent-ascent model uses in situ temperature and density at the nearest vertical level in SOSE at the location of the embryo. The depth-weight mean temperature from the depth of hatching to the surface is calculated to determine the time required for the larva to reach stage $\mathrm{CI}$, and this is assumed to be the time needed for the larva to reach the surface. Development through the later larval stages is calculated from the mean monthly in situ temperature fields

Table 2. Mortality rules implemented in the larval recruitment model for Antarctic krill

\begin{tabular}{|c|c|c|}
\hline Mortality & Model rule & References \\
\hline $\begin{array}{l}\text { M1: Spawning in sea ice } \\
\text { concentrations } \geq 80 \%\end{array}$ & $\begin{array}{l}\text { Spawning can only occur in grid cells that have } \\
\text { sea ice concentration }<80 \% \text { at the time of spawning, } \\
\text { i.e. in the open ocean or within the marginal ice zone }\end{array}$ & Siegel (2012), Stroeve et al. (2016) \\
\hline $\begin{array}{l}\text { M2: Embryo contact } \\
\text { with sea floor before } \\
\text { hatching }\end{array}$ & Embryos must hatch before reaching the sea floor & $\begin{array}{l}\text { Hofmann et al. (1992), } \\
\text { Hofmann \& Hüsrevoğlu (2003), } \\
\text { Piñones \& Fedorov (2016) }\end{array}$ \\
\hline $\begin{array}{l}\text { M3: Cold sensitivity } \\
\text { of embryos and early } \\
\text { stage larvae }\end{array}$ & $\begin{array}{l}\text { Embryo, nauplii and metanauplius stages that } \\
\text { experience an average water temperature of } \leq-1^{\circ} \mathrm{C} \\
\text { during either the developmental descent or ascent die }\end{array}$ & Ross et al. (1988) \\
\hline $\begin{array}{l}\text { M4: Starvation } \\
\text { of calyptope stages }\end{array}$ & $\begin{array}{l}\text { All calyptope stages spending } 10 \text { consecutive days } \\
\text { in sea ice concentrations }>40 \% \text { starve. Above } 40 \% \\
\text { sea ice concentration, restricted light penetration limits } \\
\text { phytoplankton development. Away from sea ice cover, } \\
\text { calyptope stages are assumed capable of finding } \\
\text { sufficient food resources to survive }\end{array}$ & $\begin{array}{l}\text { Ross \& Quetin (1989), } \\
\text { Lancelot et al. (1993) }\end{array}$ \\
\hline $\begin{array}{l}\text { M5: Overwintering } \\
\text { development stage }\end{array}$ & $\begin{array}{l}\text { Larvae must reach furcilia stage IV before the onset } \\
\text { of winter to successfully recruit. A date of } 15 \text { May } \\
\text { is used for the onset of winter }\end{array}$ & $\begin{array}{l}\text { Fraser (1936), Daly }(1990,2004), \\
\text { Frazer et al. (2002) }\end{array}$ \\
\hline $\begin{array}{l}\text { M6: Overwintering } \\
\text { habitat }\end{array}$ & $\begin{array}{l}\text { Larvae must be under sea ice at the onset of winter } \\
\text { to successfully recruit, as determined by sea ice } \\
\text { advance occurring before } 15 \text { May. Sea ice advance is } \\
\text { defined as sea ice concentration exceeding } 15 \% \\
\text { for } 5 \text { consecutive days. The onset of winter is chosen } \\
\text { to represent the period when primary productivity } \\
\text { in the Southern Ocean approaches } 0\end{array}$ & $\begin{array}{l}\text { Daly (1990), Moore \& Abbott (2000), } \\
\text { Meyer et al. (2002, 2017), } \\
\text { Behrenfeld et al. (2005), } \\
\text { Stammerjohn et al. (2008), } \\
\text { Meyer (2012) }\end{array}$ \\
\hline
\end{tabular}


linearly interpolated onto the model time step and averaged over the upper $250 \mathrm{~m}$ of the water column (upper 13 vertical levels of SOSE) to match the observations of the depth distribution of later larval stages (Fraser 1936).

The concentration of sea ice and the timing of its advance are critical in several of the mortality rules of our model, and for this we used daily satellitederived fields of sea ice concentration from the reanalysed and near real-time products of the Operational Sea Surface Temperature and Sea Ice Analysis (OSTIA; Donlon et al. 2012), available at $1 / 20^{\circ}$ horizontal resolution. The OSTIA sea ice data are, in general, in good agreement with the SOSE surface fields, but there are some areas of mismatch between surface temperature and sea ice cover, particularly as the high frequency variability in the sea ice fields is not captured when interpolating the mean monthly temperature fields onto the larval recruitment model time step. However, the areas of mismatch have minimal impact on the modelled larval development due to the rapid descent of the krill eggs from the surface layer after spawning and the use of the mean upper water column temperature for the development of the larvae once they return to the surface.

\subsection{Model implementation and initialisation}

To simulate the descent-ascent cycle and development of the krill embryos and larvae, the model uses a $1 \mathrm{~h}$ time step at which the descent of the embryo and the stage-specific development time are calculated. The proportion of the development of the current stage achieved during each time step is summed to derive a cumulative fractional development. Once fractional development of the development stage is complete, the embryo/larva progresses to the next developmental stage (Hofmann \& Hüsrevoğlu 2003).

We used an initial embryo diameter of $622 \mu \mathrm{m}$, which is in the range of observed sizes (Quetin \& Ross 1984, Jia et al. 2014). Our model results were robust to varying initial embryo diameter within the range reported to produce realistic descent profiles in the descent-ascent model (622-625 $\mu \mathrm{m}$; Hofmann \& Hüsrevoğlu 2003). To investigate intra-seasonal variability in larval recruitment success, spawning took place on 1 December 2005, 1 January 2006 and 1 February 2006. The mean position of the Polar Front (Moore et al. 1999) was assumed to form the northern boundary of the distribution of Antarctic krill (Marr 1962), and we allowed spawning to occur throughout the region south of the front, deliberately assuming no additional advance knowledge of krill spawning grounds to avoid predetermining the model outcome. Because the northernmost parts of the model domain are too remote from the autumn sea ice extent to allow successful larval recruitment to occur (mortality rule M6; Fig. 1, Table 2), using the climatological mean position of the Polar Front, rather than defining the Polar Front at the time of spawning in the model, provides an adequate northern limit to the model domain. The model simulations were run on a $1^{\circ}$ spatial grid for all grid cells with available sea ice data, with 1 egg released per grid cell. A small number of locations where the local water column properties were such that the egg did not sink during development, for example in dense water close to the Antarctic continent, were excluded from the analyses. The number of larvae modelled varied by month because of the changing environmental conditions $(\mathrm{N}=5251$ for December, $\mathrm{N}=$ 5264 for January and N = 5263 for February). Sensitivity to the date used in the overwintering mortality rules M5 and M6 (Table 2) was tested by considering the onset of winter to occur 2 and 4 wk later.

To examine interannual variability in larval recruitment success due to variability in the timing and extent of sea ice, we focussed on mid-summer spawning. We used the development rates from the January 2006 spawning event and applied the mortality rules using sea ice data from 2007-2018. Variability in the seasonal sea ice cycle affects larval recruitment success through mortality rules M1, M4 and M6 (Table 2).

\section{RESULTS}

Larval recruitment of Antarctic krill was modelled across a December to February spawning window to investigate intra-seasonal variability. In the following, we focus on the scenario of January spawning as the mid-summer situation and consider the effects of seasonality from December and February spawning in later sections. We then present the results of the investigation into interannual variability.

\subsection{Larval recruitment from mid-summer spawning}

Considering the individual sources of mortality in the larval recruitment model identifies those that place the greatest restriction on successful larval recruitment. Mortality from several of the mortality assumptions implemented in the model was low when spawning occurs in January (Fig. 2). We as- 

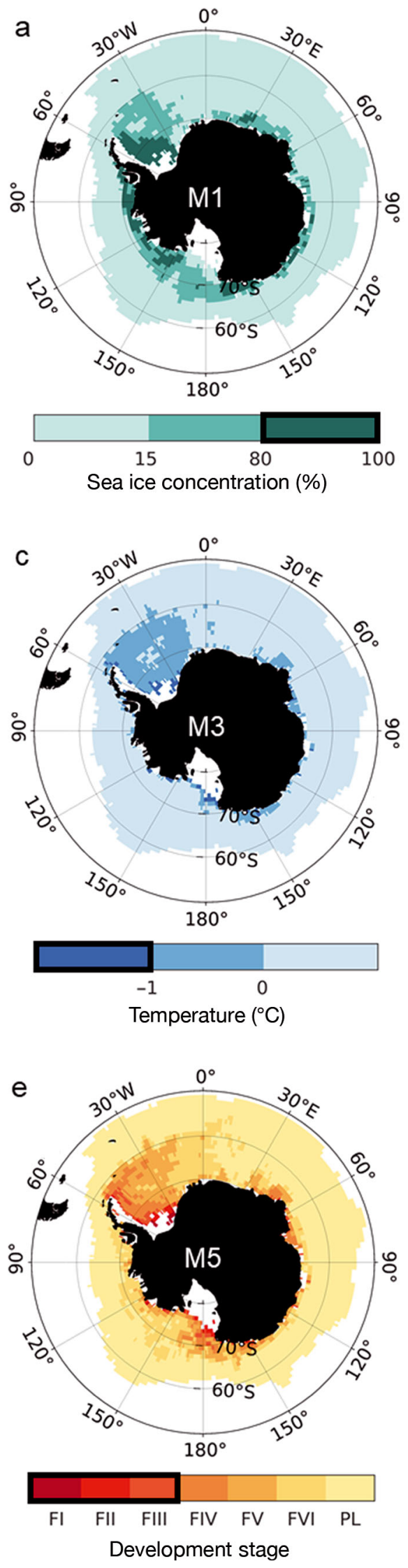

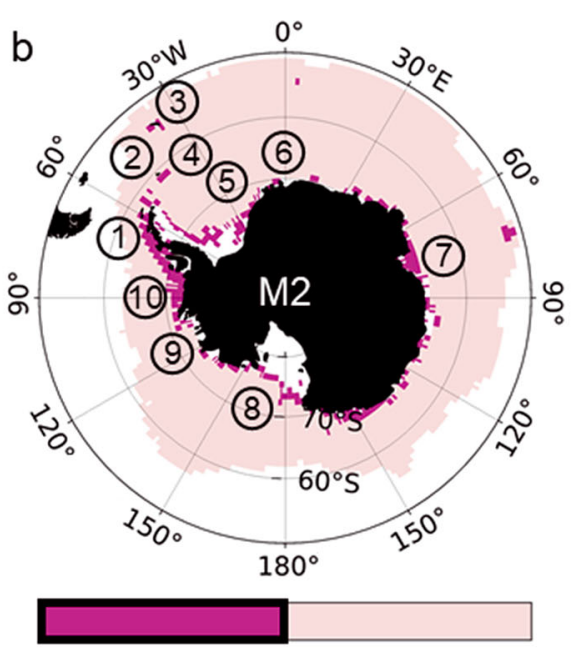

Hatch on seafloor Hatch above seafloor

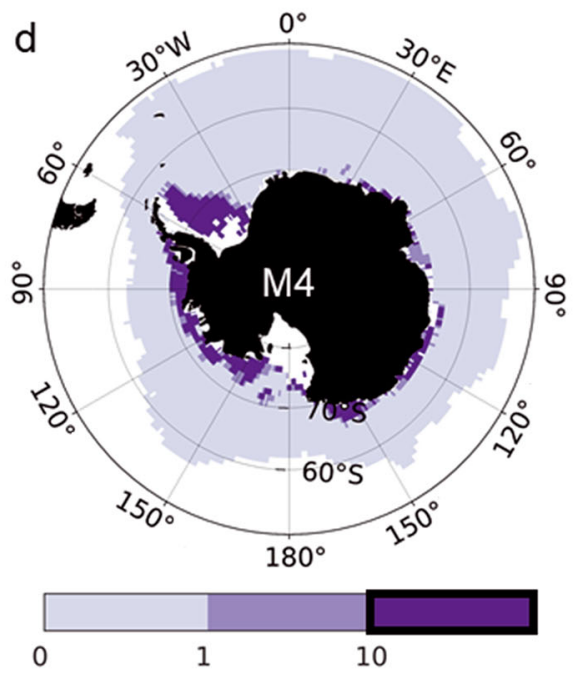

Consecutive days in sea ice for $\mathrm{Cl}-\mathrm{Clll}$ stages

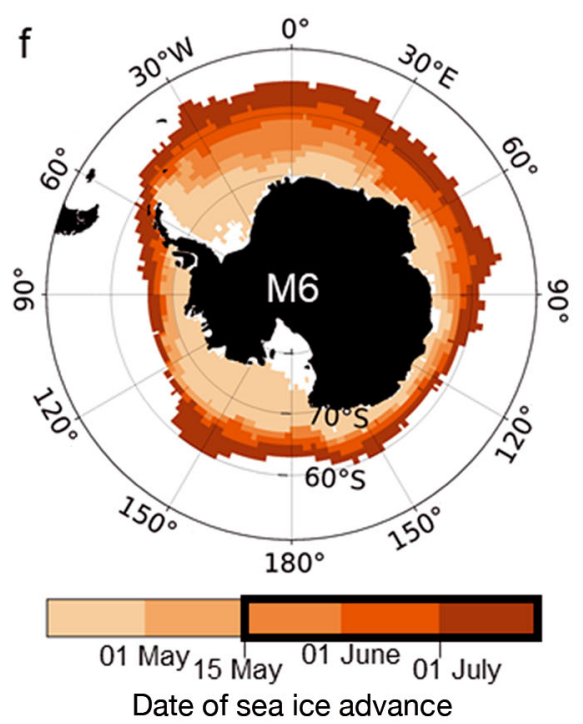

Fig. 2. Outcome of the 6 mortality rules (M1-M6) included in the Antarctic krill larval recruitment model (see Table 2) for spawning in January 2006. Mortality rules are applied independently for illustration of the relative impact of each. (a) Concentration of sea ice at spawning (M1). (b) Embryo impact with the sea floor (M2). (c) Minimum mean temperature during developmental descent and ascent (M3). (d) Maximum number of consecutive days spent by calyptope stage larvae under sea ice $>40 \%$ concentration (M4). (e) Overwintering larval developmental stage at onset of winter (15 May) (M5); F: furcilia, PL: post-larva. (f) Date of sea ice advance (M6). White areas here and in other maps indicate grid cells outside the model domain or excluded from the analysis, due either to sea ice data being unavailable or water column properties (see text for details). Values where mortality occurs in the model are outlined in black on each legend. Numbers in panel (b) indicate locations referred to in the text; 1 : western Antarctic Peninsula, 2: Scotia Sea, 3: South Georgia, 4: South Scotia Ridge, 5: Weddell Sea, 6: Lazarev Sea, 7: Cooperation Sea/Prydz Bay, 8: Ross Sea, 9: Amundsen Sea, 10: Bellingshausen Sea 
sumed that sea ice concentration determines viable spawning habitat (Table 1; mortality rule M1). In January, little pack ice remains from the winter and much of the Southern Ocean is considered suitable for spawning (Fig. 2a). Only limited areas of dense sea ice persist, prohibiting spawning in small regions close to the Antarctic continent including the southwestern Weddell Sea and the Bellingshausen and Amundsen Seas.

The developmental descent-ascent cycle has 2 associated sources of mortality: contact of the eggs with the sea floor before hatching (rule M2) and cold sensitivity of the embryos and early larval stages (rule M3). Hatching in the model takes place after approximately $5 \mathrm{~d}$ (Table 3) at depths of 530-1000 m, with shallowest hatching depths and fastest development in the northern latitudes of the model domain where temperatures are warmest. Only eggs spawned on the continental shelves around Antarctica and the sub-Antarctic islands reach the sea floor before hatching (Fig. 2b), but within these regions are localised areas where the temperature profile and water depth permit embryos to hatch. These areas include parts of the Lazarev Sea and the northern tip of the Antarctic Peninsula. All eggs spawned in deep waters off the continental shelf successfully hatch (cf. Hofmann \& Hüsrevoğlu 2003, Piñones \& Fedorov 2016). With the current model parameterisation, cold sensitivity of the early larval stages only affects a small number of larvae along the southern margins of the model domain and in the western Weddell Sea (Fig. 2c). These are areas where the krill eggs reach the seafloor before hatching.

Calyptopes are the only larval stages that can starve in the model (rule M4; Fig. 2d). Development time to reach stage $\mathrm{CI}$, and hence the ocean surface in the model, varies according to location, with larvae at $55^{\circ} \mathrm{S}$ taking approximately $23 \mathrm{~d}$ and larvae further south at $65^{\circ} \mathrm{S}$ taking $26 \mathrm{~d}$ on average (Table 3 ). These development times mean that, for larvae spawned in January, their arrival at the surface coincides with minimum sea ice extent and there are only limited areas where the larvae starve. These reflect the areas of pack ice at the time of spawning and comprise the western Weddell Sea, areas close to the Antarctic continent between 90 and $170^{\circ} \mathrm{E}$, and the Bellingshausen and Amundsen Seas. Elsewhere, there is sufficient time for the larvae to develop to furcilia stages before the advance of sea ice.

To overwinter successfully requires 2 conditions to be met. Firstly the larvae must be at a minimum development stage of FIV at the onset of winter (rule M5). Larvae that were spawned in January range in development stage from FI to post-larvae in mid-May (Fig. 2e, Table 3), with the distribution of the development stages closely mapping the temperature field. Larvae that were spawned close to the Antarctic continent, where temperatures are lowest and hence development is slowest, have not progressed beyond FI at the onset of winter. In the Weddell Gyre, the larvae range from early furcilia stages ( $\leq$ FIII) in the western and southern parts of the region to FVI stages in the east. Early furcilia stages are also found in the Ross Sea. In contrast, krill that have developed from eggs spawned in the warmer waters of the Antarctic Circumpolar Current have all reached the post-larval stage.

The second requirement is that larvae must be under sea ice at the onset of winter to ensure sufficient food for the larvae to overwinter successfully (rule M6). By the start of winter, sea ice has advanced to cover much of the southern part of the study region (Fig. 2f), and larvae that have reached the FIV stage in these areas are considered to have successfully recruited. However, much of the northern regions are ice-free at the onset of winter, including the WAP and the northeastern Weddell Sea. The later sea ice advance in these regions prevents successful larval recruitment in the model.

The model suggests that the main drivers determining viable habitat for successful larval recruitment from spawning in January are those related to sea ice, i.e. the requirement for spawning to take place away from the pack ice zone and for larvae to be under sea ice at the onset of winter (Fig. 3). Hatching above the sea floor has a small impact, but the remaining mortality assumptions only affect sites

Table 3. Mean developmental times for Antarctic krill larvae at 2 latitudes. Mean (SD) of cumulative time to reach specified developmental stages (days) for all simulated larvae spawned in January at latitudes of $55.375^{\circ} \mathrm{S}$ and $65.375^{\circ} \mathrm{S}$. n: number of grid cells at specified latitude, N: nauplius, C: calyptopis, F: furcilia, PL: post-larva. No mortality rules have been applied in these calculations

\begin{tabular}{|c|c|c|c|c|c|c|c|c|c|c|c|c|}
\hline \multirow{2}{*}{$\begin{array}{l}\text { Lati- } \\
\text { tude }\end{array}$} & \multirow[t]{2}{*}{$\mathrm{n}$} & \multicolumn{11}{|c|}{ - Time to reach specified developmental stage from spawning (d) } \\
\hline & & NI & $\mathrm{CI}$ & $\mathrm{CII}$ & CIII & FI & FII & FIII & FIV & $\mathrm{FV}$ & FVI & PL \\
\hline $55^{\circ} \mathrm{S}$ & 167 & $5.0(0.2)$ & $23.4(1.0)$ & $35.5(1.7)$ & $43.2(2.1$ & $51.7(2.5)$ & $61.9(3.0)$ & $71.2(3.4)$ & $82.2(3.9)$ & $93.2(4.4)$ & $105.9(5.0)$ & $116.0(5.5)$ \\
\hline $65^{\circ} \mathrm{S}$ & 355 & $5.6(0.6)$ & $26.0(2.5)$ & $40.6(4.4)$ & $49.8(5.8)$ & $60.0(7.1)$ & $72.2(8.8)$ & $83.3(10.3)$ & $96.5(12.2)$ & $109.9(14.1)$ & $125.4(16.4)$ & $138.1(18.3)$ \\
\hline
\end{tabular}




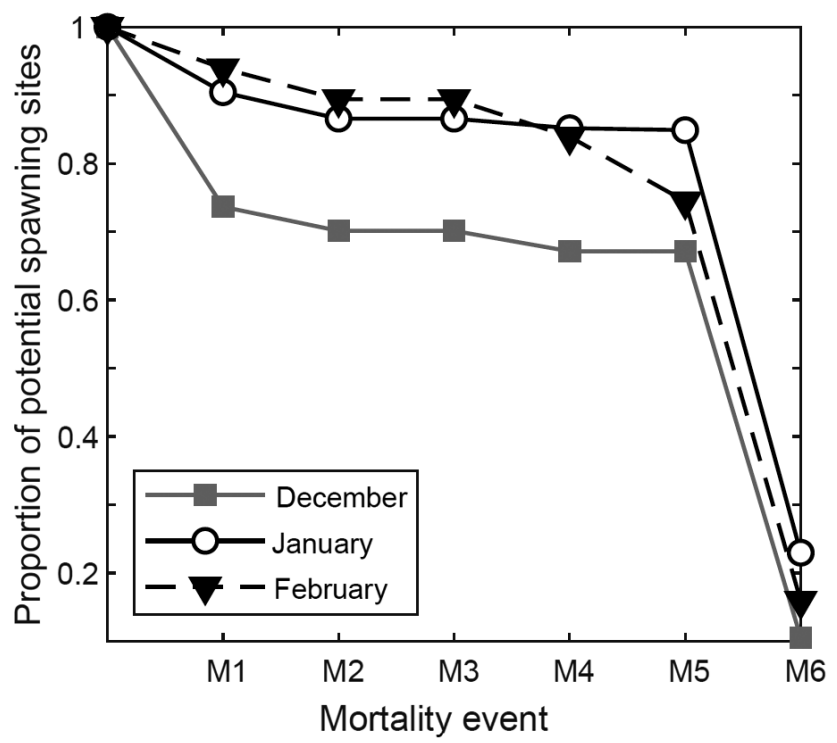

Fig. 3. Proportion of remaining viable habitat sites after implementation of each mortality rule (M1-M6) for spawning in December, January and February. See Table 2 and Fig. 2 for explanations of the mortality rules where an earlier source of mortality has prevented successful larval recruitment.

Geographically, successful larval recruitment following spawning in January is predicted to occur in a broad band at high latitude around the Antarctic continent from the tip of the Antarctic Peninsula and the northwestern Weddell Sea to the Amundsen Sea (Fig. 4a). The mortality assumptions prevent larval recruitment occurring along the WAP and in areas north of the sea ice extent in early winter. The greatest area of habitat for successful larval recruitment is predicted for the South Pacific sector of the Southern Ocean $\left(180-270^{\circ} E_{\text {; Fig. }}\right.$ ), followed by the South Atlantic sector $\left(270-0^{\circ} \mathrm{E}\right)$.

\subsection{Seasonal variability in larval recruitment success}

The timing of spawning affects the relative impact of the mortality rules. Spawning earlier in the season
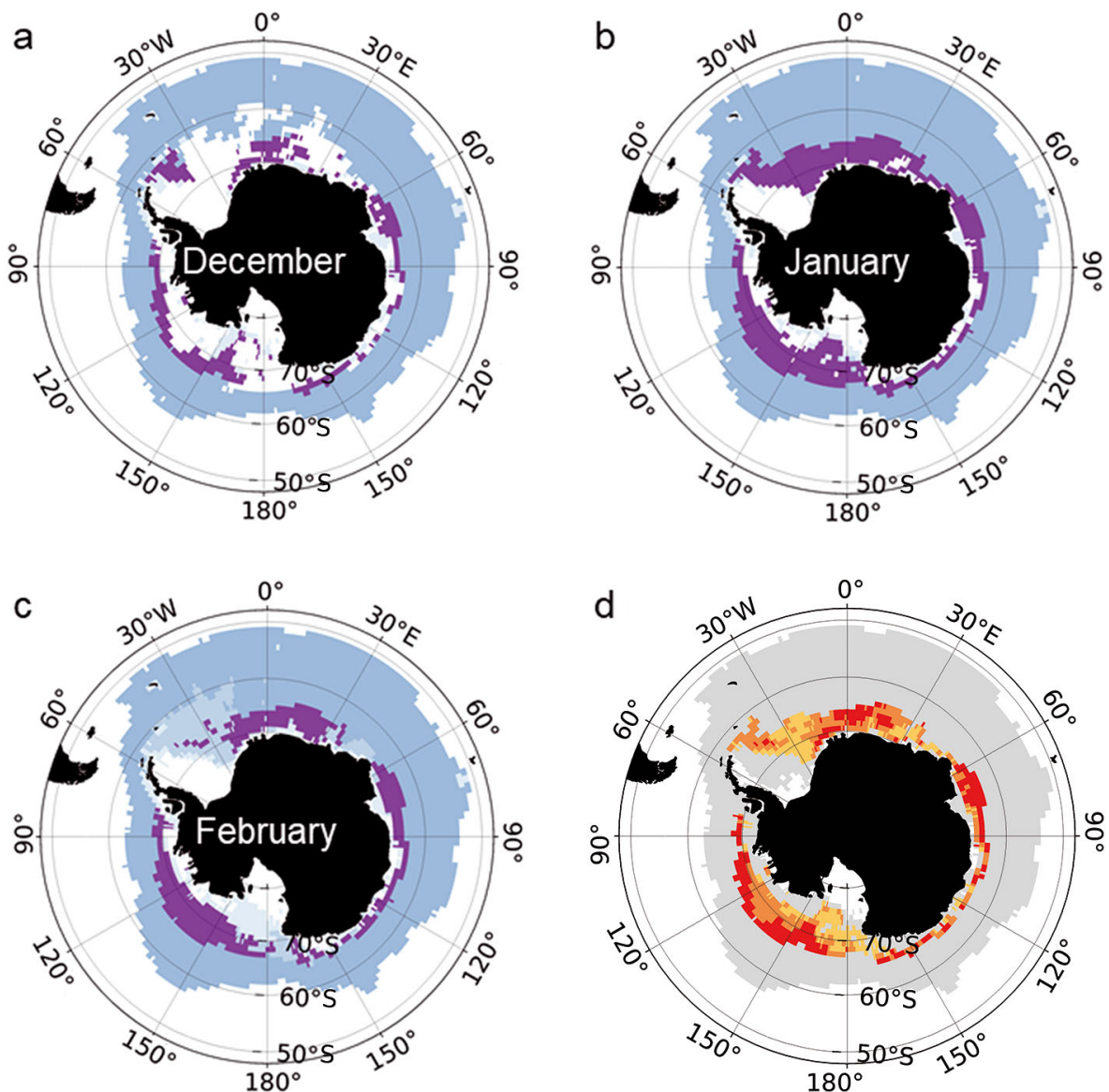

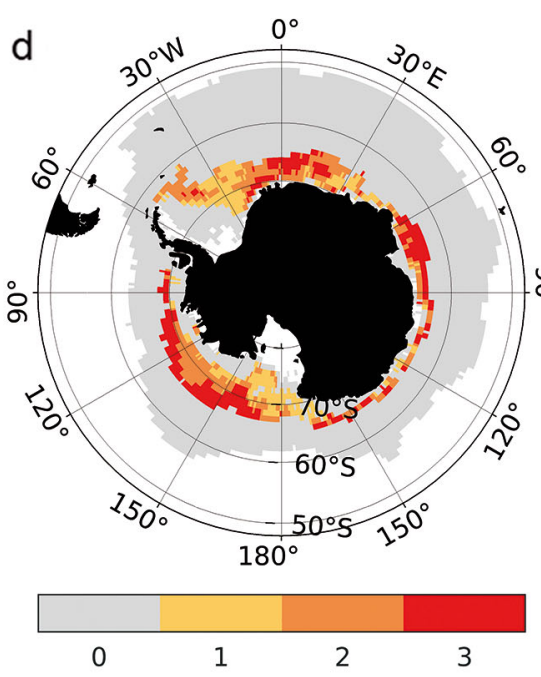

Frequency of larval recruitment (mo)
Fig. 4. Temporal and spatial distribution of successful larval recruitment. Spawning sites are shaded according to larval development stage at mid-winter for spawning in (a) December 2005, (b) January 2006 and (c) February 2006. F: furcilia, PL: post-larva. Successful larval recruitment (the 'recruit' category) requires a minimum development stage of furcilia IV (FIV) and sea ice to have advanced by the onset of winter (15 May). Additional white shading in panels $\mathrm{a}-\mathrm{C}$ indicates areas under pack ice at time of spawning. (d) Sites shaded according to frequency of successful larval recruitment from the 3 spawning events 


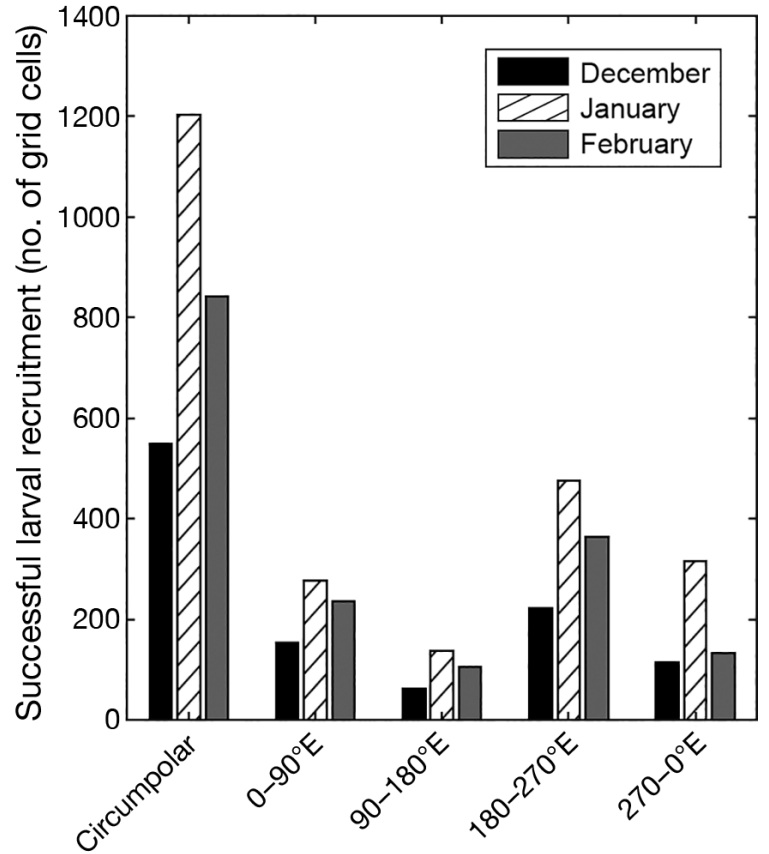

Fig. 5. Predicted larval recruitment success for the circumpolar Southern Ocean and by sector for spawning in December, January and February 2005/2006

in December results in the fewest viable spawning sites due to the increased pack ice coverage (rule M1; Fig. 3) and, as a result, the smallest area of habitat where successful larval recruitment occurs (Fig. 5). Mortality due to contact with the sea floor (rule M2) is similar to January, with very little additional habitat loss from cold sensitivity (rule M3). The earlier spawning means that some larvae develop to calyptopes in areas where the sea ice has not yet retreated, leading to starvation under the sea ice for those larvae (rule M4). There is sufficient time for the remaining larvae to develop to FIV (rule M5) but, as for January, the requirement for the larvae to be under sea ice as winter sets in (rule M6) governs successful larval recruitment habitat. Successful larval recruitment from spawning in December is patchily distributed, occurring in the northwestern and southeastern Weddell Sea, Prydz Bay, east Antarctica and from the eastern side of the Ross Sea through to the Amundsen Sea (Fig. 4a). The greatest area of successful larval recruitment habitat is again found in the South Pacific sector (Fig. 5).

In February, later in the summer, Antarctic sea ice cover is typically at its minimum and there is the smallest reduction in viable spawning habitat due to dense sea ice (rule M1; Fig. 3). Loss of habitat due to embryos reaching the sea floor before hatching (rule M2) is similar to the other months. However, there are more sites where calyptope stages starve under sea ice (rule M3) from the February spawning compared with December and January, as the later spawning leads to a greater number of larvae still at calyptope stages when the sea ice advances. There is also increased mortality depending on the development stage in winter (rule M5). The shorter time period between spawning and the onset of winter means that the larvae are at earlier stages at the onset of winter compared with those spawned earlier in the season. As with the December and January spawning events, the largest decrease in larval recruitment habitat occurs due to winter sea ice coverage (rule M6). Overall, there are fewer viable larval recruitment sites from the February spawning than January, despite greater spawning habitat, because of the shorter time for the larvae to develop before the sea ice advances (Figs. 4 \& 5). Successful larval recruitment occurs in the eastern Weddell Gyre, from Prydz Bay to $170^{\circ} \mathrm{E}$, and from the Ross Sea to the Amundsen Sea (Fig. 4c).

\subsection{Regions of larval recruitment success and failure}

The model suggests that there are a number of regions where larval recruitment is successful through the peak breeding season. Successful larval recruitment occurs for eggs spawned in December, January and February in the Lazarev Sea, north of Prydz Bay and along the margins of eastern Antarctica, and from the Ross Sea to the Bellingshausen Sea along $\sim 70^{\circ} \mathrm{S}$. There is also a more restricted area of successful larval recruitment in the northwest Weddell Sea (Fig. 4d). Larval recruitment along the South Scotia Ridge and the southern parts of the Amundsen Sea is predicted to be successful following spawning in both December and January, but not February.

In contrast, there are areas where larval recruitment is not predicted to be successful from spawning in any of the 3 months with the current set of mortality conditions in the peak breeding season. In the Scotia Sea, although there is sufficient time for the larvae to develop to FIV stage by the onset of winter from each of the spawning events, the current set of mortality rules dictate that larvae cannot survive in this region because sea ice advance occurs too late in the season, if at all (rule M6). Along the continental shelf of the northern WAP, sea ice cover does not limit spawning in any of the months of our analysis. However, many of the larvae do not survive because the embryos reach the sea floor before hatching (rule M2). In the deeper areas of the continental shelf 

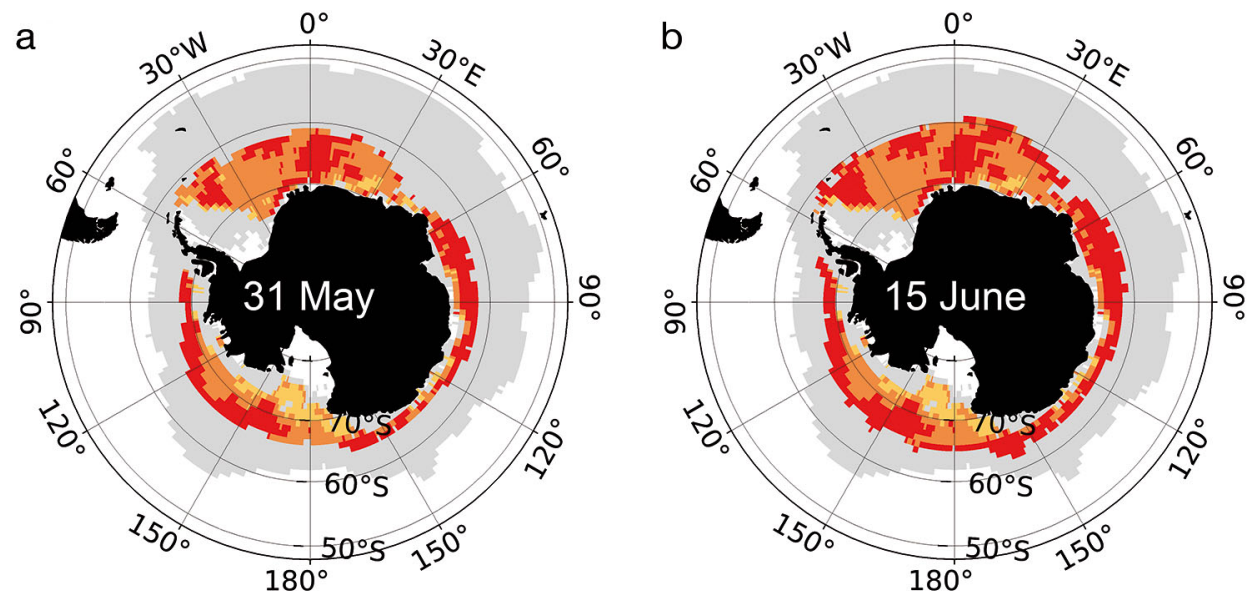

Fig. 6. Impact on larval recruitment of varying the date used for mid-winter mortality rules M5 and M6 (see Table 2 for details): (a) 31 May, (b) 15 June. Grid cells are shaded according to the number of months of successful larval recruitment from spawning events in December, January and February $2005 / 2006$

Frequency of larval recruitment (mo)

where hatching can take place above the sea floor (Fig. 2b), all larvae spawned in December and January, and a large proportion of those spawned in February, develop to FIV stage before winter (rule M5; Fig. 4). However, larval recruitment cannot take place because sea ice does not advance until later in the season (rule M6; Figs. 2f \& 4).

\subsection{Sensitivity to timing of the overwintering mortality rules}

Modifying the date used for the mortality rules associated with the onset of winter (rules M5 and M6) demonstrates the sensitivity in the model to the overwintering assumptions. A later date for the onset of winter provides a longer period of time for the larvae to complete development to a viable overwintering stage (rule M5) and allows larvae to survive for an increased period before needing to be under sea ice (rule M6). As a result, additional areas of successful larval recruitment and increased frequency of success over the productive season are predicted (Fig. 6). Applying a 2 wk delay to the cut-off date (31 May) enables larvae spawned in the central Weddell Sea in February to reach stage FIV for overwintering (Fig. 6a). By this date, sea ice has advanced further north, thereby extending the northern boundary of viable habitat in the Weddell, Cooperation and Ross Seas. The model predicts that, with this later date, larval recruitment is consistently successful in large parts of the Weddell Sea, including the northwest Weddell Sea and along the Greenwich Meridian. Delaying the date used for the onset of winter by a further 2 wk, using a cut-off date of 15 June, permits successful larval recruitment in the Bransfield Strait at the northern tip of the Antarctic Peninsula and offshelf along the southwestern Antarctic Peninsula (Fig. 6b). The limiting factor on successful larval recruitment in open-ocean areas with winter sea ice coverage now becomes sea ice concentration at spawning.

\subsection{Interannual variability in larval recruitment success}

The larval recruitment model was parameterised for the year 2005/2006 for the standard run. This showed that sea ice is the main controlling factor for successful larval recruitment, determining spawning habitat, early larval starvation and, subsequently, overwintering habitat (Fig. 3). Given that interannual variability in the seasonal sea ice cycle in the Southern Ocean is large, we re-ran the model using sea ice data for the years 2007-2018 to investigate the impact of this variability on larval recruitment success. The model runs demonstrate that variability in the timing and extent of sea ice generates substantial interannual variability in larval recruitment (Fig. 7). Considering spawning in mid-summer (January) and using a date of 15 May for the onset of winter, our model predicts that there are regions where sea ice conditions permit successful recruitment in all years examined. These areas include the Cooperation Sea, Dumont D'Urville Sea $\left(\sim 140^{\circ} \mathrm{E}\right)$, Ross Sea and smaller areas of the Weddell Sea. Although not successful in each year, the model suggests that larval 


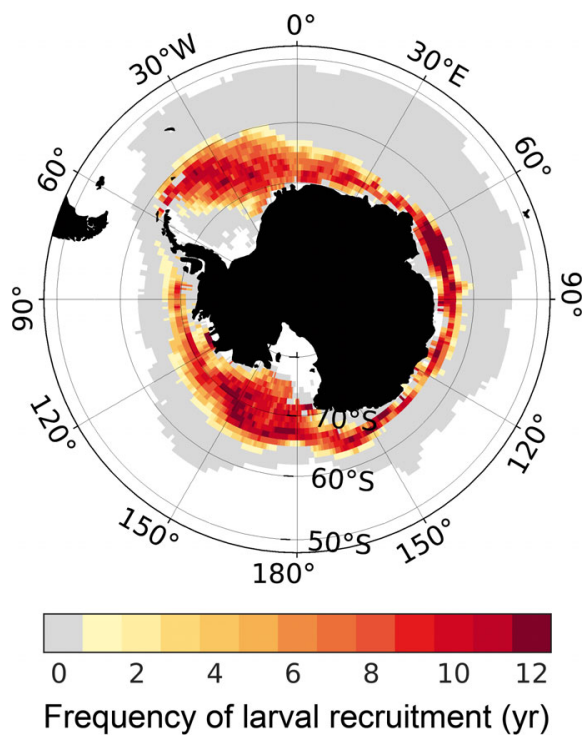

Fig. 7. Frequency (number of years) of successful larval recruitment during the period 2007-2018. Data shown are for January spawning events only, assuming mortality rules as per Table 2

recruitment could occur with high frequency in the Lazarev Sea and northwest Weddell Sea. In the Bransfield Strait, at the northern tip of the Antarctic Peninsula, the ice distribution permits spawning in all 12 years of the model run, and successful larval recruitment from mid-summer spawning depends on the early winter sea ice conditions, that is the northward extent of the sea ice and timing of advance. There is sufficient sea ice in the Bransfield Strait in early winter to allow successful larval recruitment in 9 years of the 12 yr time period, suggesting episodic larval recruitment in the Bransfield Strait. Elsewhere on the Antarctic Peninsula, the model suggests that most areas do not regularly support successful larval recruitment.

\section{DISCUSSION}

\subsection{Sea ice}

The biggest restriction to the available habitat for successful larval recruitment was the requirement for krill larvae to be under sea ice at the onset of winter. Irrespective of the timing of spawning, this rule prevents successful larval recruitment in much of the northern latitudes of the Southern Ocean, including the Scotia Sea and South Georgia, as well as parts of the WAP.

To better parameterise the habitat requirements for overwintering in the model requires further knowl- edge of the overwintering capability of larvae in the open ocean, away from sea ice. At high latitudes, larvae under sea ice may be more abundant and in better condition than larvae in the open ocean in the same region (Ross \& Quetin 1991, Daly 2004, Meyer et al. 2009, Siegel 2012). However, larvae have flexible overwintering strategies that include reducing their metabolic demands and using internal lipid reserves in low food conditions, and the capability to use both autotrophic and heterotrophic diets (e.g. Daly 1990, Frazer 1996, Meyer et al. 2009, Meyer 2012, Schmidt et al. 2014). Furthermore, larvae can tolerate periods of starvation of increasing length as their development stage advances, with stages FIVFVI able to survive a lack of food for up to a month (Daly 1990). As such, it may be possible for larval krill to sustain their metabolism either until sea ice advances later in the season or by finding other food sources during the winter. At lower latitudes, where winter light levels are not prohibitive, primary production can continue throughout the year providing sufficient resources to enable growth (Moore \& Abbott 2000, Murphy et al. 2017). Regional differences in feeding strategies, not incorporated in our model, are likely to be important (Schmidt et al. 2014). For example, Meyer et al. (2017) observed larval krill in the northern Scotia Sea in September with greater stomach fullness than larvae caught under sea ice in the same season. Such flexibility in the overwintering requirements of larval krill could greatly impact the available habitat for successful larval recruitment.

Spawning in the model was restricted to areas within the marginal ice zone and open ocean and was not allowed to occur under dense sea ice. The ability of krill to reach spawning condition depends on finding sufficient high-quality food (Cuzin-Roudy \& Labat 1992, Spiridonov 1995, Schmidt et al. 2012), and in ice-covered regions, these opportunities can be limited. However, in addition to phytoplankton blooms at the sea ice edge, phytoplankton blooms in polynyas may provide sufficient food for krill to reach spawning condition (Melnikov \& Spiridonov 1996, Kawaguchi et al. 2010, Siegel 2012). Siegel (2012) observed spent female krill and early larval stages in sea ice cover of up to $70 \%$ in the Lazarev Sea and noted that the spawning event may have been linked to increased local productivity in a polynya. It therefore appears that it is possible for females to reach spawning condition in ice regions but it may depend on local factors where productivity is enhanced, such as is found in polynyas. Thus we assumed that krill in the marginal ice zone may be able to reach spawning 
condition and allowed krill to spawn everywhere with sea ice concentration $<80 \%$. This showed that, should spawning occur, much of the marginal ice zone can lead to larvae reaching an overwintering stage at a suitable time of year and in a region where the larvae will be able to find sea ice for overwintering. Placing greater restriction on spawning under ice by allowing krill to spawn only in open water would lead to greater areas of unsuitable habitat for spawning and larval recruitment, particularly for a December spawning event when sea ice is at a greater extent than later in the summer period.

The third ice-related mortality assumption in the model assessed the likelihood of starvation of calyptope larvae. The point of no return, i.e. the period of starvation after which an organism cannot recover, is 10-14 d for calyptope-stage larval krill (Ross \& Quetin 1989). Because calyptopes do not have feeding appendages with which they can scrape food from the under-surface of sea ice, these larval stages must rely on food in the water column. At $40 \%$ sea ice cover, light transmission through the sea ice is insufficient to support phytoplankton productivity in the water column (Lancelot et al. 1993). Therefore, as a first attempt at assessing this mortality on a circumpolar scale, the model excluded areas where calyptopes spent more than 10 consecutive days under sea ice with concentration $>40 \%$. It is possible, however, that calyptopes may be able to make use of other under-ice food sources including organic material released by sea ice (Meyer et al. 2017), and our mortality assumption may therefore be too strict. Nevertheless, our results suggest that relaxing this rule would not have a large impact on the total available habitat for larval recruitment, as the areas where calyptopes are predicted to starve are generally those where pack ice has prevented spawning (cf. Fig. 2a,d). The main area to benefit would be the Ross Sea region in later spawnings, where the calyptopes encounter dense sea ice during their early development.

\subsection{Overwintering stage}

The model excluded regions where larvae have not reached FIV by late autumn. An initial cut-off date of mid-May was decided upon, since, at a circumpolar scale, this represents the date by which primary productivity in the Southern Ocean has declined to winter-time levels (Moore \& Abbott 2000, Behrenfeld et al. 2005). Larval growth and development is driven by a combination of food and temperature (Kawa- guchi 2016), and the lack of available phytoplankton at this time of year will most likely halt developmental progression. Given that the majority of surveys conducted in winter did not find earlier-stage larvae (Quetin et al. 2003, Ross et al. 2004, Flores et al. 2012, Meyer 2012, Schaafsma et al. 2016), we assumed that it is necessary to reach a stage of FIV or beyond in order to overwinter successfully. This is consistent with Daly (2004), who concluded that, at least along the WAP, larvae that had not reached FIV by June will probably not survive. This later date of June is less restrictive than the mid-May deadline set within our model, and it is possible that alternative food sources such as microzooplankton and detritus may be found at this time of year that may still drive growth and development into the early winter. The model results are sensitive to the overwintering requirements stipulated for the larvae, and we suggest that these should be an area of priority research.

As winter progresses, the larvae become increasingly food limited such that growth ceases, intermoult periods lengthen, and the size, weight and elemental content decrease (Daly 2004, Meyer 2012). Starvation tolerance becomes a major selective pressure on the larval population, with only those larvae with the greatest levels of internal reserves, particularly lipids, capable of surviving the winter (Daly 2004). In the Bellingshausen Sea, Stübing et al. (2003) measured a total lipid content in FIII-FIV larvae to be about $12 \%$ dry weight (DW) during early April 2001, while FIV-FVI larvae had a mean lipid content at that time of about $20 \%$ DW. Nevertheless, lipid levels were more moderate in autumn in late furcilia in the Weddell Sea $(18 \%$ DW, Hagen et al. 2001) and the Lazarev Sea (15\% DW, Meyer et al. 2002), meaning that there may be some further regional variability in the viability of overwintering furcilia stages. Inter-regional variability in body condition is difficult to parameterise in the present model without a better understanding of potential alternative food sources in winter and levels of lipid content and starvation tolerance in furcilia of different stages.

\subsection{Temperature}

The larval development rates in the model are driven by temperature, with warmer temperatures leading to faster development times. There is a tradeoff for successful larval recruitment between larvae occupying regions closer to the sea ice where cold temperatures reduce the development rates and may prevent the larvae reaching a sufficiently developed 
overwintering stage versus lower latitudes where warmer temperatures result in faster development rates but with the risk of not encountering sea ice for overwintering. The model suggests that larvae spawned in early and mid-summer have enough time to reach FIV by winter almost everywhere in the Southern Ocean, but there are greater restrictions for the later, February, spawning. However, years with warmer temperatures than usual in, for example, the Weddell Sea and western Ross Sea, may be able to advance development enough to reach FIV by winter.

The cold sensitivity mortality rule (M3) has little impact in its current implementation in the model. Further information on the cold sensitivity of embryos and early-stage larvae (Ross et al. 1988), in particular how long a period of exposure to cold temperature is harmful, will enable better parameterisation of this potential source of mortality.

\subsection{Sea floor hatching}

The model excluded regions where eggs reached the seafloor before hatching. This ruled out most of the regions where krill spawned over continental shelves, such as the WAP, Weddell Sea shelf and subAntarctic islands. Although the warming of the water column in the late season accelerated the rate of embryonic development, this was not sufficient to avoid hitting the sea bed before hatching could take place in these shelf regions.

The descent and ascent of the early life cycle stages was first posited by Marr (1962), who reported that, in the open ocean, eggs and early nauplii were found at depths in the range of $1000 \mathrm{~m}$. These observations were subsequently supported by Hempel (1979, 1985), although with notable spatial variability. The prevailing paradigm has therefore been that, to complete a descent-ascent cycle, spawning must occur offshore to allow eggs to hatch before encountering the seabed (Siegel 1988, Hofmann \& Hüsrevoğlu 2003). Nevertheless, the impact of reaching the seabed may not necessarily be fatal for krill eggs. Numerous egg-hatch experiments have been conducted in laboratories where contact with container walls and bottoms are inevitable (Harrington \& Ikeda 1986, Kawaguchi et al. 2013), which indicates that they must be relatively robust. Furthermore, a number of other euphausiid species have negatively buoyant eggs and maintain populations in shelf regions, including Meganyctiphanes norvegica, Euphausia pacifica and Thysanoessa spinifera (Tarling \& Cuzin-Roudy 2003, Ju et al. 2006), so some toler- ance of interactions with benthic environments must be possible. In continental shelf regions, our model found that the sea bed was often reached just 1 or $2 \mathrm{~d}$ before eventual hatching, and this may be tolerable for successful hatching. It is also possible that smaller-scale processes not included in this version of the model, such as turbulence and local upwelling, could act to reduce sinking velocities and delay eggs from hitting the sea floor or bring early-stage larvae back onto the shelf. Local circulation features may also transport eggs spawned on the outer continental shelf to deeper offshore regions where there is increased probability of successful development (e.g. Piñones et al. 2013b). Even when mortality on hitting the seabed was relaxed, however, much of the WAP would still not be viable habitat for larval recruitment because the advance of sea ice was too late in the season in those regions.

\subsection{Timing of spawning}

Our model demonstrates that successful larval recruitment habitats are a function of both spatial and temporal limitations. Furthermore, it shows that certain regions only become viable for limited windows of time when eggs can be laid, development proceeds sufficiently and a suitable overwinter habitat can be found. Physiological trade-offs mean that earlier spawning may not coincide with the period of maximum egg production. Early-stage oocytes are partially developed over the late winter and early spring, but the energy-intensive maturation of these oocytes often relies on the availability of food resources (Ross \& Quetin 2000). A major source of this food are the blooms generated by the receding ice edge, which are particularly intense through December and January (Comiso et al. 1990, Cuzin-Roudy \& Labat 1992). Krill that spawn in December may have not yet assimilated as many resources into their ovaries as those that spawn later in the year, meaning that the number of eggs produced will be sub-maximal. This sets up an offset between the optimal time of spawning, which can be earlier in the year for certain regions, and the optimal time to spawn, which will often be later with regards maximal egg production. This type of offset has been referred to as the 'parent-offspring conflict' (Trivers 1974) and may be common to a number of Antarctic pelagic organisms.

These theoretical offsets are nevertheless subject to a great deal of interannual variability, particularly regarding sea ice conditions. Physiological flexibility may allow krill to maintain their reproductive success 
despite such environmental variability. For instance, they have the capacity to spawn multiple times during a productive season. Furthermore, they can reabsorb the lipid-rich developing brood should conditions turn unfavourable, thereby increasing the overwintering reserves of the adult (Cuzin-Roudy 2000). Capturing the effects of such interannual variability is a desired further development of the present model.

\subsection{Successful regional larval recruitment habitat}

In terms of intra-seasonal variability, areas that consistently provide successful recruitment through the 2005/2006 breeding season considered in this set of simulations are predicted to be the Lazarev Sea, Prydz Bay and Cooperation Sea, east Antarctica, the northern Ross Sea, and the Amundsen and Bellingshausen Seas. Additionally, a small area of the northern Weddell Sea permits successful larval recruitment from December to February. A broader region along the South Scotia Ridge and in the northern Weddell Sea affords successful larval recruitment from the December and January spawning events. In these regions, the sea ice cycle is such that the areas are open for spawning in the summer, yet covered by ice early enough in the winter to provide the required overwintering habitat. Added to this, the prevailing temperatures permit development to the FIV stage in time for the winter sea ice advance. The longer model run investigating larval recruitment from spawning in January indicates that larval recruitment is consistently successful from mid-summer spawning in a number of these regions, namely the Cooperation, Dumont D'Urville and Ross Seas and smaller areas of the Weddell Sea. The Lazarev Sea and the northwest Weddell Sea are viable habitats for the majority of the time series. Data on larval distribution in early winter are scarce, but observations of early furcilia stages (FI-FIII) in March-April show the northern Antarctic Peninsula, Scotia Sea and the northeastern limb of the Weddell Gyre to be areas of greatest abundance in autumn (Marr 1962). Additional distribution data will inform a more detailed validation of our results.

While the conditions in the 2005/2006 season did not lead to viable larval recruitment along the Antarctic Peninsula, the model suggests that there is likely to be at least episodic recruitment from the Bransfield Strait, at the northern tip of the peninsula, in agreement with observations (Hempel 1985). Further south along the Antarctic Peninsula, a number of studies have found the WAP to contain high concen- trations of adult krill (Lascara et al. 1999, Lawson et al. 2008, Siegel et al. 2013). However, our model predicted limited successful larval recruitment due primarily to the shallow bathymetry and the timing of sea ice advance. The former is consistent with the findings of the larval development models of Hofmann \& Hüsrevoğlu (2003) and Piñones et al. (2013a), where areas of the continental shelf region were too shallow to allow the full descent-ascent cycle to take place without encountering the sea bed. Nevertheless, both these studies did find limited areas in the WAP where completion of this cycle was possible, and it is likely that higher-resolution studies of this region would show additional deeper regions where the descent-ascent cycle could be successfully completed. In reporting on the results of the Discovery Investigations, Marr (1962) found very few larvae in inshore areas of the WAP but did note that krill embryos were consistently found offshore of Marguerite Bay (southern Antarctic Peninsula), as subsequently confirmed by Siegel et al. (2013). Other regions of repeatedly high concentrations of larvae in the vicinity of the WAP have been found by further surveys, including the northern Bellingshausen Sea and areas around Bransfield Strait: north of Livingston Island, northwest of Elephant Island and the Antarctic Sound region (e.g. Witek et al. 1980, Makarov et al. 1990, Siegel et al. 2013). Within our model, conditions for successful larval recruitment were found to be particularly favourable in the Bellingshausen Sea, which agrees with the above observations. This region may be a major remote source of larval recruitment into the WAP region (Marrari et al. 2008, Siegel et al. 2013), with advection modelling indicating connectivity between these regions on timescales that would bring furcilia into the region by autumn (Piñones et al. 2013b). For instance, Mori et al. (2019) found that juvenile krill, assumed to be weak swimmers and therefore to move passively with ocean currents, were advected over distances of $\sim 50-100 \mathrm{~km}$ by mid-January when released from the ice edge between October and December. Successful larval recruitment could occur in the WAP region if embryos are able to hatch on the seafloor and the larvae can find alternative food sources until the sea ice advances. Regional model studies at higher resolution will better define the local bathymetry and sea ice dynamics.

Successful larval recruitment does not occur in the model in the western Weddell Sea or the Scotia Sea. Sea ice coverage in the western Weddell Sea prevents spawning in each of the summer months in this simulation. Net samples have found krill furcilia in 
the Scotia Sea and around South Georgia (Marr 1962, Siegel \& Watkins 2016), and our model predicts that larvae from each of the summer spawnings will successfully develop to a minimum of FIV by the onset of winter. According to our parameterisations, however, these areas may not be ultimately successful larval recruitment habitats, as sea ice advance does not occur sufficiently early for the larvae to survive to later developmental stages.

\subsection{Temporal variability}

In Fig. 8 we synthesise the factors affecting larval recruitment discussed thus far. Included in this figure is also the influence of temporal variability. What is emphasised in this figure is the prime importance of sea ice in influencing the spatial and temporal distribution of larval recruitment. Large interannual variability exists in sea ice concentration, extent and the timing of sea ice advance and retreat, linked to atmospheric signals including El Niño and the Southern Annular Mode (SAM; Liu et al. 2004, Stammerjohn et al. 2008, Turner et al. 2015). For example, a positive phase of the SAM sees increased sea ice in the eastern Ross and Amundsen Seas and decreased sea ice in the Bellingshausen and northern Weddell Seas (Liu et al. 2004). Timing in the advance and retreat of sea ice, and changes in the spatial extent and distribution of sea ice, are critical for determining the spatial distribution of successful larval recruitment from one year to the next. A year of reduced sea ice cover opens up new areas for spawning, particularly early in the summer, but may reduce overwintering success. Earlier advance of sea ice may increase larval recruitment success, provided that larvae have reached a sufficiently advanced development stage. Good larval recruitment may be expected where a low ice year is followed by a large ice year, since a greater spatial spread of spawning would occur and a larger subsequent ice cover would follow increasing overwintering survival. The pulsing of recruitment that has been observed to occur in the Antarctic Peninsula region has been related to sea ice conditions in a number of studies (Siegel \& Loeb 1995, Quetin \& Ross 2003, Loeb et al. 2009), in agreement with our model results that suggest episodic recruitment in the Bransfield Strait region due to variability in the timing of advance and the extent of winter sea ice. The model results add further weight to the need to determine this relationship better, including how it varies regionally.
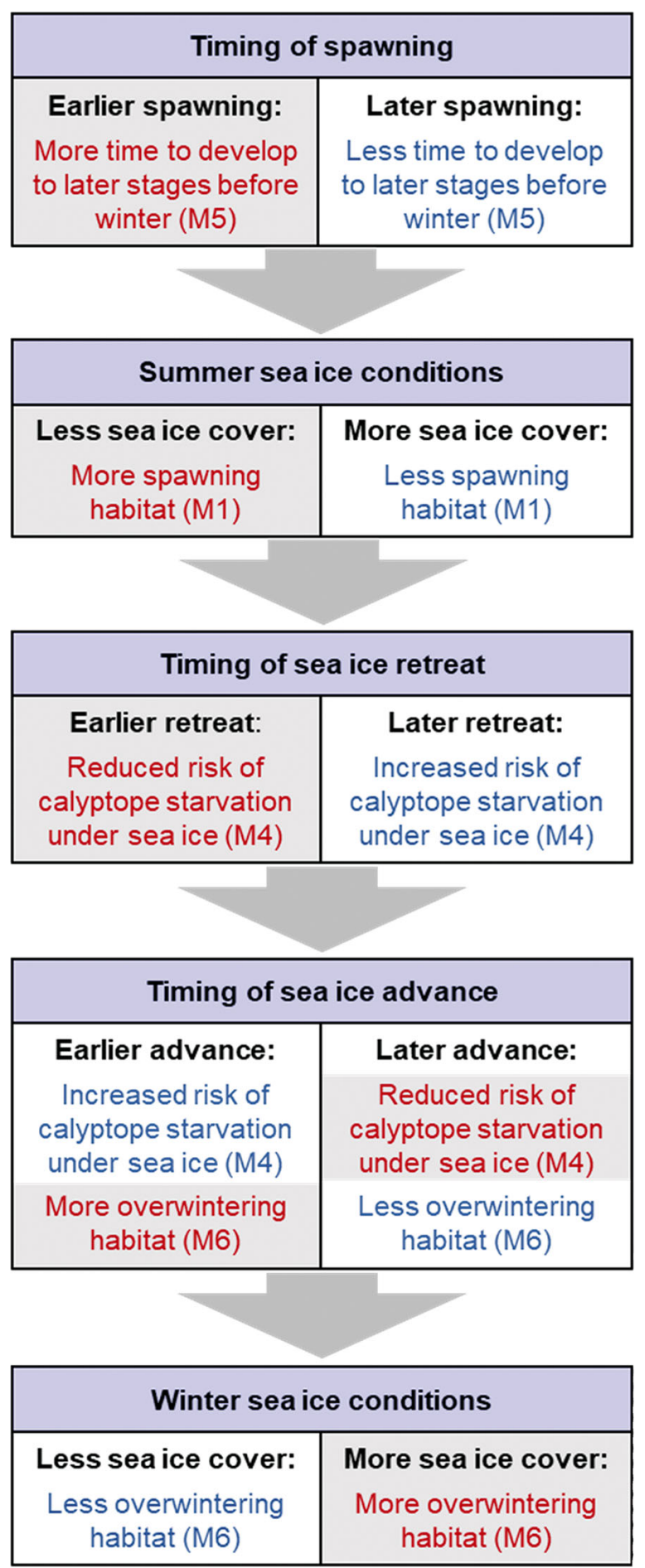

Fig. 8. Synthesis of the impacts of variability in the timing of spawning and the seasonal sea ice cycle on larval recruitment. Coloured boxes show the prime drivers of mortality in the larval recruitment model. Grey shading and red text indicate decreased mortality in response to the listed changes (leading to potentially greater larval recruitment) and blue text indicates increased mortality (leading to potentially reduced larval recruitment). M1-M6 are the mortality rules applied in the larval recruitment model; see Table 2 for details 
The temperature-driven model of larval development is also particularly sensitive to long-term change. Increasing ocean temperature (Meredith \& King 2005) would lead to more rapid development of the larvae and could potentially increase the viability of later spawning further south. Conversely, warming of the northern Southern Ocean, at the northern distributional limit of Antarctic krill, could mean that these areas are no longer suitable for larval development. A next step in our research is to include interannually varying temperature fields to drive the development component of the larval recruitment model.

\section{CONCLUSIONS}

Our larval recruitment model incorporated current knowledge of mortality in the early life cycle of Antarctic krill to further our understanding of the drivers of larval recruitment success of Antarctic krill at large scales in the Southern Ocean. Mesoscale variation will result from advection that may move larvae into viable habitats by, for example, moving larvae into warmer waters thereby accelerating their development to a stage suitable for overwintering or by transporting larvae from the open ocean into areas of sea ice cover for overwintering. Survival over winter, together with advection under sea ice, larval behaviour and the interaction between them, will determine the larval distribution in the following spring (Murphy et al. 2004, Thorpe et al. 2007, Meyer et al. 2017), and the next step in our research is to couple the larval recruitment model with an advection model. Local-scale processes not represented at the resolution of this model will also be important, particularly those affecting local sea ice dynamics and on-shelf habitats. However, our study shows that, at the large scale, sea ice is the major driver of potential larval recruitment regions, with overwintering development stage important for larvae spawned later in the productive season. Major areas of larval recruitment are expected to be the Cooperation, Ross and Weddell Seas, with further larval recruitment from mid- to late summer spawning along the South Scotia Ridge. Episodic larval recruitment is predicted from mid-summer spawning in the Bransfield Strait. Elsewhere along the WAP, immigration is likely to play an important role in determining successful larval recruitment. Regional studies at higher resolution, together with improved knowledge of the overwintering requirements for larval krill, are important for understanding the variability observed in local krill populations.
Acknowledgements. Computational resources for the Southern Ocean State Estimate (SOSE) were provided by NSF XSEDE resource grant OCE130007. We are grateful to $\mathrm{M}$. Mazloff for guidance on using SOSE output which was obtained from http://sose.ucsd.edu/sose_stateestimation_ data.html (iter59). The Operational Sea Surface Temperature and Sea Ice Analysis (OSTIA) system is run by the UK Met Office, and data were provided by EU Copernicus Marine Service Information (http://marine.copernicus.eu). We thank the editor and 3 reviewers for their constructive comments that improved this manuscript. This work was carried out as part of the Ecosystems programme at the British Antarctic Survey and Natural Environment Research Council, part of UK Research and Innovation.

\section{LITERATURE CITED}

Atkinson A, Siegel V, Pakhomov E, Rothery P (2004) Longterm decline in krill stock and increase in salps within the Southern Ocean. Nature 432:100-103

* Behrenfeld MJ, Boss E, Siegel DA, Shea DM (2005) Carbonbased ocean productivity and phytoplankton physiology from space. Global Biogeochem Cycles 19:GB1006

* Bělehrádek J (1957) Physiological aspects of heat and cold. Annu Rev Physiol 19:59-82

Byrne M (2011) Impact of ocean warming and ocean acidification on marine invertebrate life history stages: vulnerabilities and potential for persistence in a changing ocean. Oceanogr Mar Biol Annu Rev 49:1-42

Clarke A (1988) Seasonality in the Antarctic marine environment. Comp Biochem Physiol B Comp Biochem 90: 461-473

Clarke A, Tyler PA (2008) Adult Antarctic krill feeding at abyssal depths. Curr Biol 18:282-285

Comiso JC, Maynard NG, Smith WO Jr, Sullivan CW (1990) Satellite ocean color studies of Antarctic ice edges in summer and autumn. J Geophys Res Oceans 95: 9481-9496

* Conover RJ, Huntley M (1991) Copepods in ice-covered seas-Distribution, adaptations to seasonally limited food, metabolism, growth patterns and life cycle strategies in polar seas. J Mar Syst 2:1-41

Croxall JP, Reid K, Prince PA (1999) Diet, provisioning and productivity responses of marine predators to differences in availability of Antarctic krill. Mar Ecol Prog Ser 177: $115-131$

* Cuzin-Roudy J (2000) Seasonal reproduction, multiple spawning, and fecundity in northern krill, Meganyctiphanes norvegica, and Antarctic krill, Euphausia superba. Can J Fish Aquat Sci 57:6-15

Cuzin-Roudy J, Labat JP (1992) Early summer distribution of Antarctic krill sexual development in the Scotia-Weddell region: a multivariate approach. Polar Biol 12:65-74

*Daly KL (1990) Overwintering development, growth, and feeding of larval Euphausia superba in the Antarctic marginal ice zone. Limnol Oceanogr 35:1564-1576

*Daly KL (2004) Overwintering growth and development of larval Euphausia superba: an interannual comparison under varying environmental conditions west of the Antarctic Peninsula. Deep Sea Res II 51:2139-2168

* Donlon CJ, Martin M, Stark J, Roberts-Jones J, Fiedler E, Wimmer W (2012) The Operational Sea Surface Temperature and Sea Ice Analysis (OSTIA) system. Remote Sens Environ 116:140-158 
Flores H, van Franeker JA, Siegel V, Haraldsson M and others (2012) The association of Antarctic krill Euphausia superba with the under-ice habitat. PLOS ONE 7:e31775

Fraser FC (1936) On the development and distribution of the young stages of krill (Euphausia superba). Discov Rep 14:1-192

Frazer TK (1996) Stable isotope composition $\left(\delta^{13} \mathrm{C}\right.$ and $\left.\delta^{15} \mathrm{~N}\right)$ of larval krill, Euphausia superba, and two of its potential food sources in winter. J Plankton Res 18:1413-1426

Frazer TK, Ross RM, Quetin LB, Montoya JP (1997) Turnover of carbon and nitrogen during growth of larval krill, Euphausia superba Dana: a stable isotope approach. J Exp Mar Biol Ecol 212:259-275

Frazer TK, Quetin LB, Ross RM (2002) Abundance, sizes and developmental stages of larval krill, Euphausia superba, during winter in ice-covered seas west of the Antarctic Peninsula. J Plankton Res 24:1067-1077

Hagen W, Kattner G, Terbrüggen A, Van Vleet ES (2001) Lipid metabolism of the Antarctic krill Euphausia superba and its ecological implications. Mar Biol 139: 95-104

* Harrington SA, Ikeda T (1986) Laboratory observations on spawning, brood size and egg hatchability of the Antarctic krill Euphausia superba from Prydz Bay, Antarctica. Mar Biol 92:231-235

Hempel I (1979) Vertical distribution of eggs and nauplii of krill (Euphausia superba) south of Elephant Island. Meeresforschung 27:119-123

Hempel I (1985) Vertical distribution of larvae of Antarctic krill, Euphausia superba. In: Siegfried WR, Condy PR, Laws RM (eds) Antarctic nutrient cycles and food webs. Springer, Berlin, p 308-310

Hempel I, Hempel G (1986) Field observations on the developmental ascent of larval Euphausia superba (Crustacea). Polar Biol 6:121-126

Hofmann EE, Hüsrevoğlu YS (2003) A circumpolar modeling study of habitat control of Antarctic krill (Euphausia superba) reproductive success. Deep Sea Res II 50: 3121-3142

*Hofmann EE, Capella JE, Ross RM, Quetin LB (1992) Models of the early life-history of Euphausia superba. I. Time and temperature-dependence during the descent ascent cycle. Deep Sea Res A Oceanogr Res Pap 39:1177-1200

Ikeda T (1984) Development of the larvae of the Antarctic krill (Euphausia superba Dana) observed in the laboratory. J Exp Mar Biol Ecol 75:107-117

Jia Z, Virtue P, Swadling KM, Kawaguchi S (2014) A photographic documentation of the development of Antarctic krill (Euphausia superba) from egg to early juvenile. Polar Biol 37:165-179

Ju SJ, Harvey HR, Gómez-Gutiérrez J, Peterson WT (2006) The role of lipids during embryonic development of the euphausiids Euphausia pacifica and Thysanoessa spinifera. Limnol Oceanogr 51:2398-2408

Kawaguchi S (2016) Reproduction and larval development in Antarctic krill (Euphausia superba). In: Siegel V (ed) Biology and ecology of Antarctic krill. Springer International Publishing, Cham, p 225-246

Kawaguchi S, Nicol S, Virtue P, Davenport SR, Casper R, Swadling KM, Hosie GW (2010) Krill demography and large-scale distribution in the Western Indian Ocean sector of the Southern Ocean (CCAMLR Division 58.4.2) in Austral summer of 2006. Deep Sea Res II 57:934-947

Kawaguchi S, Ishida A, King R, Raymond B and others (2013) Risk maps for Antarctic krill under projected
Southern Ocean acidification. Nat Clim Chang 3: 843-847

Kohlbach D, Lange BA, Schaafsma FL, David C and others (2017) Ice algae-produced carbon is critical for overwintering of Antarctic krill Euphausia superba. Front Mar Sci 4:310

Kancelot C, Mathot S, Veth C, de Baar H (1993) Factors controlling phytoplankton ice-edge blooms in the marginal ice-zone of the northwestern Weddell Sea during sea ice retreat 1988: field observations and mathematical modelling. Polar Biol 13:377-387

* Lascara CM, Hofmann EE, Ross RM, Quetin LB (1999) Seasonal variability in the distribution of Antarctic krill, Euphausia superba, west of the Antarctic Peninsula. Deep Sea Res I 46:951-984

* Lawson GL, Wiebe PH, Ashjian CJ, Stanton TK (2008) Euphausiid distribution along the Western Antarctic Peninsula - Part B: Distribution of euphausiid aggregations and biomass, and associations with environmental features. Deep Sea Res II 55:432-454

*Liu J, Curry JA, Martinson DG (2004) Interpretation of recent Antarctic sea ice variability. Geophys Res Lett 31: L02205

K Loeb V, Siegel V, Holm-Hansen O, Hewitt R, Fraser W, Trivelpiece W, Trivelpiece S (1997) Effects of sea-ice extent and krill or salp dominance on the Antarctic food web. Nature 387:897

Loeb VJ, Hofmann EE, Klinck JM, Holm-Hansen O, White WB (2009) ENSO and variability of the Antarctic Peninsula pelagic marine ecosystem. Antarct Sci 21:135-148

Makarov R, Menshenina L, Spiridonov V (1990) Distributional ecology of euphausiid larvae in the Antarctic Peninsula region and adjacent waters. Proc NIPR Symp Polar Biol 3:23-35

Marr J (1962) The natural history and geography of the Antarctic krill (Euphausia superba Dana). Discov Rep 32: 33-464

*Marrari M, Daly KL, Hu C (2008) Spatial and temporal variability of SeaWiFS chlorophyll a distributions west of the Antarctic Peninsula: implications for krill production. Deep Sea Res II 55:377-392

Marschall HP (1983) Sinking speed, density and size of euphausiid eggs. Meeresforschung 30:1-9

Mazloff MR, Heimbach P, Wunsch C (2010) An eddy-permitting Southern Ocean state estimate. J Phys Oceanogr 40:880-899

Melbourne-Thomas J, Corney SP, Trebilco R, Meiners KM and others (2016) Under ice habitats for Antarctic krill larvae: Could less mean more under climate warming? Geophys Res Lett 43:10322-10327

Melnikov IA, Spiridonov VA (1996) Antarctic krill under perennial sea ice in the western Weddell Sea. Antarct Sci 8:323-329

Meredith MP, King JC (2005) Rapid climate change in the ocean west of the Antarctic Peninsula during the second half of the 20th century. Geophys Res Lett 32:L19604

*Meyer B (2012) The overwintering of Antarctic krill, Euphausia superba, from an ecophysiological perspective. Polar Biol 35:15-37

* Meyer B, Atkinson A, Stöbing D, Oettl B, Hagen W, Bathmann UV (2002) Feeding and energy budgets of Antarctic krill Euphausia superba at the onset of winter. I. Furcilia III larvae. Limnol Oceanogr 47:943-952

Meyer B, Fuentes V, Guerra C, Schmidt K and others (2009) Physiology, growth, and development of larval krill 
Euphausia superba in autumn and winter in the Lazarev Sea, Antarctica. Limnol Oceanogr 54:1595-1614

Meyer B, Freier U, Grimm V, Groeneveld J and others (2017) The winter pack-ice zone provides a sheltered but food-poor habitat for larval Antarctic krill. Nat Ecol Evol 1:1853-1861

Moore JK, Abbott MR (2000) Phytoplankton chlorophyll distributions and primary production in the Southern Ocean. J Geophys Res Oceans 105:28709-28722

Moore JK, Abbott MR, Richman JG (1999) Location and dynamics of the Antarctic Polar Front from satellite sea surface temperature data. J Geophys Res Oceans 104: 3059-3073

Mori M, Corney SP, Melbourne-Thomas J, Klocker A, Kawaguchi S, Constable A, Sumner M (2019) Modelling dispersal of juvenile krill released from the Antarctic ice edge: ecosystem implications of ocean movement. J Mar Syst 189:50-61

Murphy EJ, Thorpe SE, Watkins JL, Hewitt R (2004) Modeling the krill transport pathways in the Scotia Sea: spatial and environmental connections generating the seasonal distribution of krill. Deep Sea Res II 51:1435-1456

Murphy EJ, Watkins JL, Trathan PN, Reid K and others (2007) Spatial and temporal operation of the Scotia Sea ecosystem: a review of large-scale links in a krill centred food web. Philos Trans R Soc B 362:113-148

* Murphy EJ, Thorpe SE, Tarling GA, Watkins JL, Fielding S, Underwood P (2017) Restricted regions of enhanced growth of Antarctic krill in the circumpolar Southern Ocean. Sci Rep 7:6963

Piñones A, Fedorov AV (2016) Projected changes of Antarctic krill habitat by the end of the 21 st century. Geophys Res Lett 43:8580-8589

Piñones A, Hofmann EE, Daly KL, Dinniman MS, Klinck JM (2013a) Modeling environmental controls on the transport and fate of early life stages of Antarctic krill (Euphausia superba) on the western Antarctic Peninsula continental shelf. Deep Sea Res I 82:17-31

Piñones A, Hofmann EE, Daly KL, Dinniman MS, Klinck JM (2013b) Modeling the remote and local connectivity of Antarctic krill populations along the western Antarctic Peninsula. Mar Ecol Prog Ser 481:69-92

Quetin LB, Ross RM (1984) Depth distribution of developing Euphausia superba embryos, predicted from sinking rates. Mar Biol 79:47-53

* Quetin LB, Ross RM (2003) Episodic recruitment in Antarctic krill Euphausia superba in the Palmer LTER study region. Mar Ecol Prog Ser 259:185-200

Quetin LB, Ross RM, Clarke A (1994) Krill energetics: seasonal and environmental aspects of the physiology of Antarctic krill, Euphausia superba. In: El-Sayed SZ (ed) Southern Ocean ecology: the BIOMASS perspective. Cambridge University Press, Cambridge, p 165-184

Quetin LB, Ross RM, Frazer TK, Amsler MO, Wyatt-Evens C, Oakes SA (2003) Growth of larval krill, Euphausia superba, in fall and winter west of the Antarctic Peninsula. Mar Biol 143:833-843

Ratnarajah L, Bowie AR (2016) Nutrient cycling: Are Antarctic krill a previously overlooked source in the marine iron cycle? Curr Biol 26:R884-R887

Ross RM, Quetin LB (1989) Energetic cost to develop to the 1st feeding stage of Euphausia superba Dana and the effect of delays in food availability. J Exp Mar Biol Ecol 133:103-127

Ross RM, Quetin L (1991) Ecological physiology of larval euphausids, Euphausia superba (Euphausiacea). Mem Queensl Mus 31:321-333

Ross R, Quetin L (2000) Reproduction in Euphausiacea. In: Everson I (ed) Krill. Blackwell Science, London, p 150-181

Ross RM, Quetin LB, Kirsch E (1988) Effect of temperature on developmental times and survival of early larval stages of Euphausia superba Dana. J Exp Mar Biol Ecol 121:55-71

Ross RM, Quetin LB, Newberger T, Oakes SA (2004) Growth and behavior of larval krill (Euphausia superba) under the ice in late winter 2001 west of the Antarctic Peninsula. Deep Sea Res II 51:2169-2184

Schaafsma FL, David C, Pakhomov EA, Hunt BPV, Lange BA, Flores H, van Franeker JA (2016) Size and stage composition of age class 0 Antarctic krill (Euphausia superba) in the ice-water interface layer during winter/ early spring. Polar Biol 39:1515-1526

Schmidt K, Atkinson A, Venables HJ, Pond DW (2012) Early spawning of Antarctic krill in the Scotia Sea is fuelled by 'superfluous' feeding on non-ice associated phytoplankton blooms. Deep Sea Res II 59-60:159-172

Schmidt K, Atkinson A, Pond DW, Ireland LC (2014) Feeding and overwintering of Antarctic krill across its major habitats: the role of sea ice cover, water depth, and phytoplankton abundance. Limnol Oceanogr 59: $17-36$

Schmidt K, Schlosser C, Atkinson A, Fielding S, Venables HJ, Waluda CM, Achterberg EP (2016) Zooplankton gut passage mobilizes lithogenic iron for ocean productivity. Curr Biol 26:2667-2673

Siegel V (1988) A concept of seasonal variation of krill (Euphausia superba) distribution and abundance west of the Antarctic Peninsula. In: Sahrhage D (ed) Antarctic Ocean and resources variability. Springer, Berlin, p 219-230

Siegel V (2012) Krill stocks in high latitudes of the Antarctic Lazarev Sea: seasonal and interannual variation in distribution, abundance and demography. Polar Biol 35: 1151-1177

* Siegel V, Loeb V (1995) Recruitment of Antarctic krill Euphausia superba and possible causes for its variability. Mar Ecol Prog Ser 123:45-56

Siegel V, Watkins JL (2016) Distribution, biomass and demography of Antarctic krill, Euphausia superba. In: Siegel V (ed) Biology and ecology of Antarctic krill. Springer International Publishing, Cham, p 21-100

Siegel V, Reiss CS, Dietrich KS, Haraldsson M, Rohardt G (2013) Distribution and abundance of Antarctic krill (Euphausia superba) along the Antarctic Peninsula. Deep Sea Res I 77:63-74

Smetacek V, Nicol S (2005) Polar ocean ecosystems in a changing world. Nature 437:362-368

Spiridonov VA (1995) Spatial and temporal variability in reproductive timing of Antarctic krill (Euphausia superba Dana). Polar Biol 15:161-174

Stammerjohn SE, Martinson DG, Smith RC, Yuan X, Rind D (2008) Trends in Antarctic annual sea ice retreat and advance and their relation to El Niño-Southern Oscillation and Southern Annular Mode variability. J Geophys Res Oceans 113:C03S90

Stroeve JC, Jenouvrier S, Campbell GG, Barbraud C, Delord K (2016) Mapping and assessing variability in the Antarctic marginal ice zone, pack ice and coastal polynyas in two sea ice algorithms with implications on 
breeding success of snow petrels. Cryosphere 10: 1823-1843

Stübing D, Hagen W, Schmidt K (2003) On the use of lipid biomarkers in marine food web analyses: an experimental case study on the Antarctic krill, Euphausia superba. Limnol Oceanogr 48:1685-1700

Tarling GA, Cuzin-Roudy J (2003) Synchronization in the molting and spawning activity of northern krill (Meganyctiphanes norvegica) and its effect on recruitment. Limnol Oceanogr 48:2020-2033

Tarling GA, Thorpe SE (2017) Oceanic swarms of Antarctic krill perform satiation sinking. Proc R Soc B 284: 20172015

Thomas DN, Dieckmann GS (2002) Biogeochemistry of

Editorial responsibility: Alejandro Gallego, Aberdeen, UK
Antarctic sea ice. Oceanogr Mar Biol Annu Rev 40: 143-169

* Thorpe SE, Murphy EJ, Watkins JL (2007) Circumpolar connections between Antarctic krill (Euphausia superba Dana) populations: investigating the roles of ocean and sea ice transport. Deep Sea Res I 54:792-810

Trivers RL (1974) Parent-offspring conflict. Am Zool 14: 249-264

Turner J, Hosking JS, Bracegirdle TJ, Marshall GJ, Phillips $T$ (2015) Recent changes in Antarctic sea ice. Philos Trans R Soc A 373:20140163

Witek Z, Koronkiewicz A, Soszka GJ (1980) Certain aspects of the early life history of krill Euphausia superba Dana (Crustacea). Pol Polar Res 1:97-115

Submitted: September 25, 2018; Accepted: February 7, 2019 Proofs received from author(s): March 5, 2019 